\title{
WPS3501
}

\section{Telecommunications Reform within Russia's Accession to the World Trade Organization}

\author{
by \\ Jesper Jensen, Copenhagen Economics \\ Thomas Rutherford, University of Colorado
}

and

David Tarr, The World Bank*

Email of the corresponding author: DTARR@WORLDBANK.ORG

World Bank Policy Research Working Paper 3501, February 2005

The Policy Research Working Paper Series disseminates the findings of work in progress to encourage the exchange of ideas about development issues. An objective of the series is to get the findings out quickly, even if the presentations are less than fully polished. The papers carry the names of the authors and should be cited accordingly. The findings, interpretations, and conclusions expressed in this paper are entirely those of the authors. They do not necessarily represent the view of the World Bank, its Executive Directors, or the countries they represent. Policy Research Working Papers are available online at http:/lecon.worldbank.org.

*We thank Ksenia Yudaeva, S. Baranov, Vladimir Klimushin and his colleagues at ZNIIS, Fukunari Kimura, Mitsuyo Ando, Takamune Fujii, Eshref Trushin, Ekaterina Krivonos, Oleksandr Shepotylo and Maria Kasilag. We thank the United Kingdom's Department for International Development for financial support. 


\title{
Non-Technical Summary
}

In World Trade Organization (WTO) accession negotiations, telecommunications is always a sector that receives close scrutiny by the WTO Working Party, and the extent of market access and nondiscriminatory treatment of multinational telecommunications companies in Russia has been a significant issue in Russia's accession negotiations. We employ a computable general equilibrium model of the Russian economy to assess the role of telecommunications in the discussions regarding Russian accession to the WTO.

We assume that, as part of its accession to the WTO, Russia will make commitments to multinational telecommunications services providers that will lead to greater foreign direct investment in telecommunications. We estimate that this will have three key effects:

\author{
1. The Russian economy will expand and labor productivity will increase. We estimate that \\ the Russian economy will gain 1.6 percent of the value of Russian consumption in the medium \\ term and potentially much greater long-term gains. Russian users of telecommunications services \\ will obtain a reduction in the quality-adjusted prices. This has a impact of increasing the \\ productivity of Russian labor and capital, because they will work with better of lower cost \\ telecommunications services.
}

\section{Employment of Russian telecommunications workers should increase. We}

estimate that employment of skilled and unskilled Russian labor in the telecommunications sector will likely increase when more multinational firms locate in Russia. Although employment is likely to decrease in purely Russian firms, multinationals also demand Russian labor. Due to an expansion of demand for 
telecommunications services and the fact that multinational telecommunications services providers in Russia employ mostly Russian labor, liberalization of barriers to foreign direct investment in telecommunications services in Russia either independently or within the context of WTO accession should increase demand for labor in the telecommunication sector.

\section{Russian capital owners in telecommunications will likely gain or lose depending on their}

joint venture status. We estimate that multinational telecommunications services providers will expand their activities in Russia. Multinationals will typically look for Russian joint venture partners when they want to invest in Russia. Thus, many of the wholly owned Russian firms are likely to become part of joint ventures with foreign investors, and this will likely preserve or increase the value of their investments. On the other hand, there will be a significant decline in the market share of wholly owned Russian telecommunications firms. Thus, Russian capital owners in the telecommunication sector who remain wholly independent of multinational firms will see the value of their investments decline. Since more competitive modern firms are likely to be most valued by foreign investors, Russian firms have increased incentive to modernize and become competitive. Restructuring may not only make Russian firms more efficient, it may also allow them to reap profits from joint venture investments in an environment with more foreign investment. 


\title{
Telecommunications Reform within Russia's Accession to the World Trade Organization
}

\author{
by
}

\section{Jesper Jensen, Thomas Rutherford and David Tarr}

In all World Trade Organization (WTO) accession discussions potential members negotiate with the Working Party of the WTO regarding the extent to which they will make commitments in the services sectors that will provide foreign investors access to the services markets of the new members on the same basis as their home country nationals.

Telecommunications is always a sector that receives close scrutiny by the Working Party, and the extent of market access and nondiscriminatory treatment of multinational telecommunications companies in Russia has been a significant issue in its accession negotiations. Most notably, the European Union-Russia bilateral protocol of accession, signed on May 21, 2004, calls for an end to the Rostelekom monopoly on long distance telephone services within Russia.

Some Russian telecommunications service providers have expressed a fear of a negative impact from WTO accession since they believe that liberalized rules on new foreign direct investment will lead to increased competition from multinational telecommunications providers in Russia. At the same time we ask: shouldn't skilled Russian telecommunications workers expect to gain from an increased demand for their services as multinational telecommunications companies invest in Russia? Shouldn't commercial and consumer users of telecommunications services benefit from increased telecommunications competition and a wider variety of available telecommunications technologies that increased foreign direct investment (FDI) will bring, and if so, how large a benefit to the Russian economy would this be? Finally, won't multinational telecommunications companies often look for Russian partners with local expertise, and won't this allow existing Russian telecommunications companies to restructure themselves as joint venture partners with multinationals? What will happen to Russian telecommunications services providers who are not sought as joint venture partners? 
Jensen, Rutherford and Tarr (2004a; 2004b) have developed a computable general equilibrium model of the Russian economy to analyze the impact of WTO accession on the aggregate Russian economy and the principal sectors in the economy. A key feature of this model is that multinational service providers compete with domestic service providers through foreign direct investment. Liberalization of discriminatory barriers against multinational service providers induces entry by multinationals which results in endogenous productivity gains in downstream industries that use the service through the well-known Dixit-Stiglitz-Ethier mechanism. ${ }^{1}$ In this paper, we update that model for the telecommunications sector and employ the updated version to provide estimates of the impact of Russian WTO accession on the telecommunications sector, and of liberalization of Russian barriers on FDI in telecommunications on the economy.

Regarding Russian WTO accession in general, we explain in Jensen, Rutherford and Tarr (2004a) that the gains from Russian accession to the WTO derive from four principal effects: (1) improved access to the markets of non-CIS countries in selected products, ${ }^{2}$ (2) Russian tariff reduction; ${ }^{3}$ (3) liberalization of barriers to foreign direct investment in services; and (4) potential growth effects from improvement in the investment climate. Among these, it is the liberalization of barriers to foreign direct investment in services that is most relevant to the telecommunications sector. In this regard, a growing body of evidence and economic theory suggests that the close availability of a diverse set of business services (like telecommunications services) is important for economic growth. The key idea in the literature is that a diverse set (or higher quality set) of business services allows users to purchase a quality adjusted unit of business services at lower cost. ${ }^{4}$ Russian commitments will encourage multinational service providers to increase foreign

\footnotetext{
${ }^{1}$ Domestic service providers exit, but the total number of service providers increases.

${ }^{2}$ WTO accession will grant an "injury determination" to Russia in antidumping cases in WTO members countries. Combined with the decision by the US to treat Russia as a market economy will imply Russian exporters may have considerably improved rights in these cases in the US. But market economy status may be denied in particular cases, so it will be necessary to see how this is implemented in practice.

${ }^{3}$ Romer (1994) has emphasized that the impact of trade liberalization on new or higher quality products is much more important quantitatively than improved resource allocation.

${ }^{4}$ As early as the 1960s, the urban and regional economics literature (e.g., Greenfield, 1966; Jacobs, 1969, 1984; Chinitz 1961; Vernon 1960; Stanback, 1979) recognized the importance of non-tradable intermediate
} 
direct investment to supply the Russian market. Russian businesses will then have improved access to the services of multinational service providers in areas like telecommunications, banking, insurance, transportation and other business services. This should lower the cost of doing business and increase productivity of Russian firms using these services. Our analysis is innovative in applying this methodology to an important service sector within a multi-sector model of an economy where services are provided both by multinational service providers through foreign direct investment and domestic presence as well as through cross-border provision of services. ${ }^{5}$

We estimate that it is liberalization of barriers to foreign direct investment in services that is the most important part of Russian accession to the WTO--it accounts for about a 5.9 percent increase in Russian consumption in the medium term, which is about three-quarters of the gains to Russia from WTO accession in the medium term. In this paper, we show that elimination of barriers to FDI in telecommunications alone will result in a gain in Russian consumption of 1.6 percent of Russian consumption. Symmetrically, we estimate that if Russia were to accede to the WTO without a reduction in barriers to FDI in telecommunications, the gains to Russia would be reduced by 1.6 percent of Russian consumption. Thus, reduction of barriers to FDI in telecommunications is one of the more important commitments that Russia could make at the WTO in order to improve Russian real income.

goods (primarily producer services produced under conditions of increasing returns to scale) as an important source of agglomeration externalities which account for the formation of cities and industrial complexes, and explanations of the difference in economic performance across regions.

${ }^{5}$ There have been a number of theoretical papers on this subject, including several by Markusen and various co-authors. Regarding numerical efforts, Markusen, Rutherford and Tarr (2002) developed a stylized model where foreign direct investment is required for entry of new multinational competitors in services, but they did not apply this model to the data of an actual economy. Brown and Stern (2001) and Dee et al. (2003) employ a multi-country numerical model with many of the same features of Markusen, Rutherford and Tarr. Their models contain three sectors, agriculture, manufacturing and services, and are thus also rather stylized. Results in their model depend crucially on capital flows between nations or (in Dee et al.) the loss of rents by multinationals after service sector liberalization, as opposed to microeconomic endogenous productivity effects. There have also been numerical estimates of the benefits of services liberalization where services trade is treated analogously to goods trade, i.e. trade in services is assumed to be entirely cross-border and subject to tariffs. For example, see Brown, Deardorf, Fox and Stern (1996). 
We estimate that employment of skilled and unskilled Russian labor in the telecommunications sector will likely increase when more multinational firms locate in Russia. Although employment is likely to decrease in purely Russian firms, multinationals also demand Russian labor, even though they use Russian labor less intensively than Russian firms. Given our parameter values, liberalization of barriers to foreign direct investment in telecommunications services in Russia either independently or within the context of WTO accession should increase demand for labor in the telecommunications sector.

We estimate that multinational telecommunications services providers will expand their activities in Russia. Multinationals will typically look for Russian joint venture partners when they want to invest in Russia. Thus, many of the wholly owned Russian firms are likely to become part of joint ventures with foreign investors, and this will likely preserve or increase the value of their investments. On the other hand, there will be a significant decline in the market share of wholly owned Russian telecommunications firms. Thus, Russian capital owners in the telecommunications sector who remain wholly independent of multinational firms will see the value of their investments decline.

The paper is organized as follows. In section II, we briefly describe the model and the most important data. In section III, we describe and interpret the policy scenarios and quantitatively assess the sensitivity of the results to parameter assumptions. In section IV, we briefly conclude.

\section{Overview of the Model and Data}

Formal characterization of the model and description of the general dataset is provided in Jensen, Rutherford and Tarr (2004b). Here we provide a brief overview of the model and focus on the features that are most relevant to the evaluation of telecommunications reform. Before we describe the features of the model, we first briefly summarize the key mechanism in the 
model that leads to large estimated gains from liberalization of FDI in services as well as some of the empirical evidence for this formulation.

\section{Intuition for the Results}

The key feature of the model that drives the large estimated welfare gains is our assumption that users of business services (and also imperfectly produced goods) are able to increase their productivity when a greater variety (or larger number) of business services (or imperfectly produced goods) are available. To take a simple and stark example, suppose the Russian economy had one billion dollars to spend on machine tools. Compare two situationsone where there is only one machine tool available and another where there are 1,000 machine tools available. Clearly, users of machine tools in different sectors of the economy will be able to select machine tools that more closely meet their production requirements with 1,000 machine tools available as opposed to only one machine tool. Thus, the one billion dollars spent on machine tools will result in much greater output with the larger number of machine tools. More generally we assume that productivity in using industries increases with greater variety of business services or imperfectly competitive goods.

Liberalization of barriers against foreign direct investment encourages additional multinational suppliers of business services to enter the Russian market. Similarly, reduction of tariff barriers against foreign goods suppliers encourages more foreign goods suppliers to enter the Russian market. Although there will be a decline of purely Russian firms in the sector, on balance there is an increase in the varieties of service providers in the market. The net increase in the number of service providers increases the productivity of users of business services. 


\section{Evidence on the Productivity Impact of Liberalization of Barriers Against Foreign Direct Investment in Services and on Goods}

Services Sector Liberalization. A growing body of evidence and economic theory suggests that the close availability of a diverse set of business services is important for economic growth. The key idea is that a diverse set (or higher quality set) of business services allows users to purchase a quality adjusted unit of business services at lower cost. As early as the $1960 \mathrm{~s}$, the urban and regional economics literature argued that non-tradable intermediate goods (primarily producer services produced under conditions of increasing returns to scale) are an important source of agglomeration externalities which account for the formation of cities and industrial complexes, and account for differences in economic performance across regions. The more recent economic geography literature (e.g., Fujita, Krugman and Venables, 1999) has also focused on the fact that related economic activity is economically concentrated due to agglomeration externalities (e.g., computer businesses in Silicon Valley, ceramic tiles in Sassuolo, Italy). Evidence comes from a variety of sources. Ciccone and Hall (1996) show that firms operating in economically dense areas are more productive than firms operating in relative isolation. Hummels (1995) shows that most of the richest countries in the world are clustered in relatively small regions of Europe, North America and East Asia, while the poor countries are spread around the rest of the world. He argues this is partly explained by transportation costs for inputs since it is more expensive to buy specialized inputs in countries that are far away for the countries where a large variety of such inputs are located. Marshall (1988) shows that in three regions in the United Kingdom (Birmingham, Leeds and Manchester) almost 80 percent of the services purchased by manufacturers were bought from suppliers within the same region. He cites studies which show that firm performance is enhanced by the local 
availability of producer services. In developing countries, McKee (1988) argues that the local availability of producer services is very important for the development of leading industrial sectors.

Productivity Effects from Goods Liberalization. As Romer (1994) argues, product variety is a crucial and often overlooked source of gains to the economy from trade liberalization. Broda and Weinstein find that increased product variety contributes to a fall of 1.2 percent per year in the "true" import price index. In our model, it is greater availability of varieties that is the engine of productivity growth, but we believe there are other mechanisms as well through which trade may increase productivity. ${ }^{6}$ Consequently, we take variety as a metaphor for the various ways increased trade in goods can increase productivity. Winters et al. (2004) summarize the empirical literature by concluding that "the recent empirical evidence seems to suggest that openness and trade liberalization have a strong influence on productivity and its rate of change."

\section{The Model}

There are 35 sectors in the model that are listed in Table 1 . There are three primary factors of production in all sectors: unskilled labor, skilled labor and capital. There are three types of sectors: competitive, imperfectly competitive goods sectors and imperfectly competitive business services sectors. The structure of production is depicted in figure 1 .

Competitive Sectors. One category of sectors is those in which goods and services that are produced under constant returns to scale and where price equals marginal costs. This includes agriculture, forestry and construction. It also includes certain public services, like education and post office facilities, and key mineral industries. ${ }^{7}$ In these sectors, domestic firms face

\footnotetext{
${ }^{6}$ Trade liberalization may induce firms to move down their average cost curves, or import higher quality products or shift production to more efficient firms within an industry. Tybout and Westbrook (1995) find evidence of this latter type of rationalization for Mexican manufacturing firms.

${ }^{7}$ To reflect the use of exhaustible resources, we assume capital is sector specific in oil, gas and coal. This implies there are decreasing returns to scale in the variable factors, skilled and unskilled labor, in these three sectors. Although electricity and gas are monopolistically controlled, prices are controlled by the
} 
competition from foreign producers where we assume that the quality of goods produced domestically and by foreign firms are differentiated in the demand functions of Russian consumers and firms. This is known as the Armington assumption. All Russian goods producing firms (including imperfectly competitive firms) can sell on the domestic market or export, but there are quality differences between the domestic and export goods. ${ }^{8}$

Imperfectly Competitive Goods. A second category of sectors is those goods that are produced under increasing returns to scale and imperfect competition, such as ferrous metals, non-ferrous metals and chemicals. There are both foreign and domestic firms competing to supply these products in the Russian market. Foreign firms supply the Russian market with production facilities abroad, but the number of foreign firms that are present in the Russian market depends on profitability in the Russian market, which in turn depends on the tariff rate. Tariff liberalization will typically lead to productivity gains because when more varieties are available, buyers can obtain varieties that more closely fit their demands and needs. ${ }^{9}$

government. Thus, market determined pricing to exploit market power is excluded by the government, and we maintain the assumption of price equal to marginal costs.

${ }^{8}$ Russian firms substitution possibilities are represented by a constant elasticity of transformation production possibility frontier.

${ }^{9}$ The efficiency gains associated with an increased number of varieties accrue to both consumers and firms using these goods as intermediate inputs.

Goods produced subject to increasing returns to scale are differentiated at the firm level; firms in these industries set prices such that marginal cost equals marginal revenue; and there is free entry, which drives profits to zero. We assume that there is a fixed cost with constant marginal costs. We employ the standard Chamberlinian large group monopolistic competition assumption, which results in constant markups over marginal cost.

Aggregate productivity is affected by the number of varieties using the standard Dixit-Stiglitz formulation. The effective cost function for users of goods produced subject to increasing returns to scale declines in the total number of firms in the industry.

For simplicity we assume that the composition of fixed and marginal cost is identical in all increasing returns to scale sectors. This implies that the ratio of fixed to marginal cost is a constant. This assumption in a standard Chamberlinian large-group model assures that output per firm for all firm types remains constant, i.e., the model does not produce rationalization gains or losses. We assume that manufactured goods are either produced domestically or imported, and the cost structure of domestic firms is defined by observed primary factor and intermediate inputs to that sector in the base year data. The cif import price of foreign goods is simply defined by the import price, and, by the zero profits assumption, in equilibrium the import price must cover fixed and marginal costs of foreign firms. 
Business Services Sectors. The third category of sectors is services sectors that are produced in Russia under increasing returns to scale and imperfect competition, such as telecommunications, financial services, most business services and transportation services. In services sectors, we observe that some services are provided by foreign service providers on a cross border basis analogous to goods providers from abroad. In the case of telecommunications, long distance telecommunication service between Russia and foreign countries typically entails provision of services by foreign telecommunications companies without a physical presence in Russia. But typically the majority of business services are provided by service providers with a domestic presence. Our model allows for both types of service provision in these sectors. There are cross border services allowed in this sector and they are provided from abroad at constant costs - this is analogous to competitive provision of goods from abroad. Cross border services, however, are not good substitutes for service providers who have a presence in Russia. ${ }^{10}$ There are two types of service firms in these sectors that have a domestic presence in Russia: Russian firms and multinational firms. There are multinational service firm providers that choose to establish a presence in Russia in order to compete with Russian firms directly in the Russian market. Multinational service providers will import some of their technology or management expertise when they decide to establish a domestic presence in Russia. Thus, their cost structure differs from Russian service providers. They incur costs related to both imported inputs and Russian primary factors, in addition to intermediate factor inputs. Domestic service providers import intermediate inputs, but do not import management expertise or possibly specialized technology available only their multinational competitors. Hence, domestic service firms incur primary factor costs related to Russian labor and capital only. These services are characterized by firm-level product differentiation. Restrictions on foreign direct investment, right of establishment, the movement of business personnel, and lack of intellectual property protection

\footnotetext{
${ }^{10}$ Empirical work has traditionally treated producer services as non-traded. See Kravis and Lipsey (1988). Daniels (1985) found that service providers charge higher prices when the service is provided at a distance.
} 
and contract enforcement have major, direct impacts on multinational firms providing services to the market.

The number of multinational and Russian firms that are present in the Russian market depends on profitability in the Russian market. For multinational firms, the barriers to foreign direct investment affect the profitability. Reduction in the constraints on foreign direct investment will typically lead to productivity gains because when more varieties of service providers are available, buyers can obtain varieties that more closely fit their demands and needs. ${ }^{11}$

We believe (as the urban economics literature suggested), wide availability of producer services leads to important productivity gains. Many business services are either non-traded internationally or provided at much higher costs from a distance so that there are significant disadvantages to a user of these services from being far from the core location of these activities. Marshall (1988) shows that in three regions in the United Kingdom (Birmingham, Leeds and Manchester) almost 80 percent of the services purchased by manufacturers were bought from suppliers within the same region. He cites studies which show that firm performance is enhanced by the local availability of producer services. In developing countries, McKee (1988) argues that the local availability of producer services is very important for the development of leading industrial sectors. ${ }^{12}$

\footnotetext{
${ }^{11}$ We assume that the structure of both the marginal and fixed costs of services firms are identical, so that as was the case in goods production, output per firm is fixed and there are no rationalization gains. For multinational service providers, both the fixed and variable costs of service supply are assumed to be a convex combination of the domestic supply price in the same sector and the cost of imported inputs.

12 The more recent economic geography literature (e.g., Krugman, 1991; Porter, 1992; Fujita, Krugman and Venables, 1999) has also focused on the fact that related economic activity is economically concentrated due to agglomeration externalities (e.g., computer businesses in Silicon Valley, ceramic tiles in Sassuolo, Italy). Evidence comes from a variety of sources. Ciccone and Hall (1996) show that firms operating in economically dense areas are more productive than firms operating in relative isolation. Caballero and Lyons (1992) show that productivity increases in industries when output of its input supplying industries increases. Hummels (1995) shows that most of the richest countries in the world are clustered in relatively small regions of Europe, North America and East Asia, while the poor countries are spread around the rest of the world. He argues this is partly explained by transportation costs for inputs since it is more expensive to buy specialized inputs in countries that are far away for the countries where a large variety of such inputs are located.
} 


\section{Consumer Optimization, Government Revenue and the Balance of Trade}

Constraint. Consumers maximize utility subject to their budget constraint. The government collects a variety of indirect taxes (output, intermediate, tariffs, investment, consumption, exports, and public consumption). In any counterfactual in which we lower tariffs, government revenue must increase to offset the lost revenue from tariff reduction (equal government yield constraint). In any counterfactual, the change in the value of imports must equal the change in the value of exports (balance of trade constraint), i.e., any capital flows are held constant since the trade policy changes cannot be presumed to effect the underlying reasons for capital flows.

Distribution of the Rents from the Barriers on Multinationals. One issue in assessing the consequences of elimination of the barriers against FDI in business services sectors is what is the nature of the barrier initially and if it is a quantitative restraint, what happens to the quota rents. We model this three ways: (1) all the rents are dissipated through rent seeking; (2) no rent dissipation and Russians capture the rents; and (3) no rent dissipation and multinationals capture the rents.

Rent dissipation follows from the conventional theory of rent seeking, for example from the model of Barzel (1974). Suppose the barrier takes the form of a license to operate. Given that the license to operate has value, competition among license seekers will result in real resources being used in lobbying costs, queuing costs and inefficiencies in the cost of the delivery that dissipate the rents. That is, multinationals purchase Russian capital and labor for the purpose of obtaining the license. Elimination of the barriers would eliminate the rent from obtaining the license and eliminate the wasteful use of resources on rent seeking behavior. Thus, this view of license allocation implies there are real resource gains from elimination of barriers to FDI since Russian labor and capital devoted to acquisition of the license becomes available.

No rent dissipation would occur if recipients of the licenses are unable to influence the decision on who gets the licenses. That is, the size of the firm or any payments on lobbying of officials is irrelevant regarding the receipt of the license. With no rent dissipation, we must make 
a further decision on who captures the rents. Russians may capture the rents as payments from multinationals. Or possibly there are discriminatory taxes on multinationals that are captured by the Russian government. In either of these cases, the rents are not lost to the Russian economy.

Alternatively, when a multinational firm receives the license to import, it receives a windfall profit equal to the ad valorem equivalent of the quota. In this latter case, we assume multinationals capture this rent on their sales in Russia and repatriate this profit. We take no rent dissipation and Russians capturing the rents as our central assumption, but estimate the impact of alternate assumptions in the sensitivity analysis. With rent dissipation or multinationals capturing the rents, the elimination of the barriers results in more resources being available in Russia and larger gains to the Russian economy.

Comparative Steady State Formulation. In this version of our model, we approximate the improved impact that we expect to see on the investment climate as a result of accession to the WTO. If the investment climate improves, we would expect to observe an increase in the capital stock available and an increase in production and consumption. We expect the investment climate to improve because the costs of purchasing goods and services as inputs for businesses falls with a reduction in tariffs and the barriers to foreign direct investment. We model and quantify the impact of an increase in investment from this effect. ${ }^{13}$ A second way WTO accession

\footnotetext{
${ }^{13}$ The rate of return on investment in our model is the rental rate on capital divided by the cost of a unit of the capital good. In this version we allow the capital stock to adjust to its steady state equilibrium along with all of the model features we employ in our WTO reference case, i.e., we allow for tariff and FDI liberalization with endogenous productivity effects as above. We call this our comparative steady state model. In the comparative static model, we assume that the capital stock is fixed and the rental rate on capital is endogenously determined. In the comparative steady state model, the logic is reversed. We assume that the capital stock is in its initial steady state equilibrium in the benchmark dataset, but that the capital stock will adjust to a new steady state equilibrium based on a fixed rate of return demanded by investors. That is, if the trade policy shock happens to induce and increase in the rate of return on capital so that it exceeds the initial rate of return, investors will invest and expand the capital stock. Expansion of the capital stock drives down the marginal product of capital, i.e., it drives down the rental rate on capital, until the rate of return on capital falls back to the initial level. The comparative steady approach has been employed by many authors, including Harrison, Rutherford and Tarr $(1996,1997)$ and Baldwin and Francois (1999). The approach, however, dates back to the 1970s, when both Koopmans and Manne used it.
} 
could improve the investment climate is through implementation of more transparent rules and regulations that guarantee the rights of investors. In our modeling, we do not estimate the impact of this second effect, which is likely to be an important gain from WTO accession.

\section{Data $^{14}$}

Input-output table. The core input-output model is the 1995 table produced by

Goskomstat. The official table contained only 22 sectors, and importantly has little service sector disaggregation. Post and telecommunications were combined in one sector. Consequently, Russian input-output expert S. P. Baranov disaggregated this table into a 35 sector input output table. Baranov used unpublished data available to Goskomstat based on the surveys that were used to construct the 1995 table. The principal elements of this disaggregation were: a split of the oil and gas sector into oil, gas and oil processing; a split of the transport sector into railroad, maritime, air, pipeline, truck and other transportation services; the breakup of communication into post services and telecommunications; and disaggregation of the data in several business services sectors regarding market and non-market activities. The documentation by Baranov is available upon request to the authors. Data on value added, exports and imports by sector are listed in Jensen, Rutherford and Tarr (2004a).

Telecommunications Update. For the purposes of the present study, we also updated the data on value-added in telecommunications and the demand for telecommunications to account for the strong growth in this sector since 1995. First, we observe that value added in the 1995 input output table we have was 0.89 percent of economy-wide value added. We estimate that value added in telecommunications in 2001 was 1.43 percent of the economy. ${ }^{15}$ To properly

\footnotetext{
${ }^{14}$ See Jensen, Rutherford and Tarr (2004a) for explanation of the tariff and export tax data.

${ }^{15}$ We have data on value-added only of the combined post and telecommunications sectors; but we have separate data on the revenues of these two sectors. Between 1995 and 2002, the share of telecommunications in the two sectors continually increased. Post declined during this period, due to competition from electronic services such as email and internet, while these factors and mobile telephone services led to growth in the telecommunication sector during most of the period. .Data on revenues in telecommunication and post services Goskomstat (2003a, p 44).were used to disaggregate the shares of
} 
account for the expanded role of telecommunications in Russia by the year 2001, we scaled up

the coefficients for telecommunications demand in both intermediate and final demand by a factor of 1.6 (1.43/.89). As we discuss, this adjustment has a significant impact on the results.

\section{Share of Expatriate Labor Employed by Multinational Telecommunications Service}

\section{Providers}

The impact of liberalization of barriers to foreign direct investment in telecommunications on the demand for labor in this sector will depend on the share of expatriate labor used by multinational firms. If multinationals use mostly Russian labor, their expansion is likely to increase the demand for Russian labor in these sectors. ${ }^{16}$ We obtained estimates of the share of expatriate labor or specialized technology not available to Russian firms that is used by multinational service providers in Russia from ZNIIS (a Russian research institute that specializes in telecommunications). ZNIIS estimated that multinational telecommunication service providers use mostly Russian primary factor inputs and only small amounts of expatriate labor or specialized technology. In particular, the estimated share of foreign inputs used by multinationals telecommunication service providers is 10 percent plus or minus 2 percent $^{17}$

value added in the two separate sectors. The share of telecommunication services in the combined sector increased from $77 \%$ to $88 \%$ during $1995-2002$

Our estimates also indicate that the input output table underestimated the importance of telecommunications in 1995. We estimate that value added in telecommunications in Russia in 1995 was 1.12 percent, not 0.89 percent as reported in the input output table. Input-output authorities must reconcile data from different sources and the balancing process results in changes in most of the underlying data. Given our focus on telecommunications, we chose to impose the actual demand for telecommunications. Thus, we are adjusting for both the growth in demand in telecommunications since 1995 as well as the underestimate of telecommunication demand in 1995.

${ }^{16}$ See Markusen, Rutherford and Tarr (2000) for a detailed explanation on why FDI may be a partial equilibrium substitute for domestic labor but a general equilibrium complement.

${ }^{17}$ The estimated shares were similar in other business services sectors: financial services, 3 percent, plus or minus 2 percent; maritime transportation, 3 percent, plus or minus 2 percent; and air transportation, 12.5 percent, plus or minus 2.5 percent. We thank Vladimir Klimushin of ZNIIS for the telecommunications estimates; Dmitri Grishankov and Irina Shuvalova of ExpertRA for the estimates for banking, insurance and securities; Boris Rybak and Dmitry Manakov of InfoMost for the estimates for air transportation; and Tamara Novikova, Juri Ivanov and Vladimir Vasiliev of CNIIMF for the maritime transportation estimates. 
Barriers to Foreign Direct Investment in Telecommunications. World-wide, discriminatory treatment of multinational FDI takes many forms. Barriers include bans on FDI in certain sectors, limitations on the share of ownership of a company, location conditions, minimum capital requirements, compulsory joint ventures, government approval of some decisions or compulsory government board members, restrictions on foreign shareholder rights, export requirements, local content restrictions, restrictions on imports of labor and capital, limits on repatriation of profits and license requirements for certain operations. ${ }^{18}$

Among the key restrictions against multinational service providers in Russia are:

Rostelecom maintains a monopoly on long distance fixed-line telephone services, affiliate branches of foreign banks are prohibited, and there is a quota on the multinational share of the insurance market. ${ }^{19}$ Estimates of the ad valorem equivalence of these and other barriers to FDI in services are key to the results. Consequently, we commissioned 20 page surveys from Russian research institutes that specialize in these sectors and econometric estimates of these barriers based on these surveys.

These questionnaires provided us with data and descriptions and assessments of the regulatory environment in these sectors. ${ }^{20}$ Using this information and interviews with specialist staff in Russia, as well as supplementary information, Kimura, Ando and Fujii (2004a, 2004b, 2004c) then estimated the ad valorem equivalence of barriers to foreign direct investment in several Russian sectors, namely in telecommunications; banking, insurance and securities; and

\footnotetext{
${ }^{18}$ See UNCTAD (1996) or Brown and Stern (2001, table 2) for a more complete list.

${ }^{19}$ The protocol on Russian accession signed between the European Union and Russia on May 21, 2004 calls for the termination of the Rostelekom monopoly by 2007 and allows for an increase in the upper limit on the multinational share of the Russian insurance market. See UNCTAD (1996) or Brown and Stern (2001, table 2) for a complete list of barriers to FDI worldwide.

${ }^{20}$ ZNIIS in the case of telecommunications, Expert RA for banking, insurance and securities; Central Marine Research and Design Institute (CNIIMF) for maritime transportation services and Infomost for air transportation services. We thank Vladimir Klimushin of ZNIIS; Dmitri Grishankov and Irina Shuvalova of ExpertRA; Boris Rybak and Dmitry Manakov of InfoMost; and Tamara Novikova, Juri Ivanov and Vladimir Vasiliev of CNIIMF. The questionnaires are available at www.worldbank.org/trade/russia-wto. The same experts provided the data on share of expatriate labor discussed below.
} 
maritime and air transportation services. The process involved converting the answers and data of the questionnaires into an index of restrictiveness in each industry. Kimura et al. then applied methodology explained in the volume by C. Findlay and T. Warren (2000), notably papers by Warren (2000), McGuire and Schuele (2000) and Kang (2000). For each of these service sectors, authors in the Findlay and Warren volume evaluated the regulatory environment across many countries; the same regulatory criteria were assessed for all countries in a particular service sector. The price of services is then regressed against the regulatory barriers to determine the impact of any of the regulatory barriers on the price of services. Kimura et al then assumed that the international regression applies to Russia. Applying that regression and their assessments from the questionnaires, they estimated the ad valorem impact of a reduction in barriers to foreign direct investment in these services sectors. ${ }^{21}$ The results of the estimates are listed in table $2 .^{22}$ In

21 Warren estimated quantity impacts and then using elasticity estimates was able to obtain price impacts. The estimates by Kimura et al. that we employ are for "discriminatory" barriers against foreign direct investment. Kimura et al. also estimate the impact of barriers on investment in services that are the sum of discriminatory and non-discriminatory barriers.

Earlier estimates for these sectors, using the same methodology we provided by Zemnitsky (2001) in financial services and telecommunications and by Sokolov (2002) in external maritime services. These latter estimates, however, were not informed by questionnaires or interviews with experts in the sectors.

22 Kimura et al. estimated that the price of telecommunications services in Russia are elevated by $10 \%$ due to barriers to multinational service providers. We believe that in telecommunications it is crucial to employ a differentiated product model to characterize competition between multinational and Russian telecommunications providers. This means that we interpret the estimates of Kimura et al. to indicate that the discriminatory tax on multinational service providers results in a $10 \%$ increase in the composite price of domestic and multinational service provision. Then the ad valorem tax on multinationals, say at rate $\mathrm{x}$, must be above $10 \%$ since there is no discriminatory tax on domestic service providers and the composite price is a weighted average of domestic prices (which are untaxed) and multinational prices which are taxed at a rate $\mathrm{x}$. More precisely, if $\mathrm{x}$ is the ad valorem equivalent of the barriers to multinational investment in telecommunications in Russia, $\mathrm{s}$ is the share of the market in Russia of multinationals, $10 \%$ is the amount by which telecommunications prices are elevated due to the barriers and if we assume Russian domestic service providers prices are unaffected, then we may solve for $\mathrm{x}$ from: $\mathrm{sx}+(1-\mathrm{s}) * 0=.10$. That is, $\mathrm{x}=.10 / \mathrm{s}$ Our data indicate that $\mathrm{s}=.15$, then $\mathrm{x}=.67$ or $67 \%$.

Barriers to foreign direct investment, however, have an indirect effect on the price of Russian telecommunications services. Consequently, $\mathrm{sx}+(1-\mathrm{s})^{*} \mathrm{y}=.10$ may be more appropriate, where $\mathrm{y}$ is the amount by which Russian telecommunication services are increased in the benchmark as a result of barriers on multinational telecommunications service providers. The value of y would have to be less than the value of the increase in composite services (0.1). It is likely that the indirect effect of barriers to foreign direct investment on the price of domestic Russian telecommunications services is less than 0.05 , since the composite price increased by only 0.1 and lower values of y yield higher estimates of $\mathrm{x}$. But if we take $y=.05$, then $x$ equals 0.38 , which is approximately the value estimated for financial services, of 0.33 . We take a conservative estimate here of 0.33 for telecommunications. 
the case of maritime and air transportation services, we assume that the barrier will only be cut by 15 percentage points, since pressure from the Working Party in these sectors is not strong.

\section{Policy Results}

We now discuss the results of our analysis of liberalization of the barriers to FDI in the telecommunications sector in Russia, both with and independent of wider liberalization undertaken with the context of WTO accession. The results include both aggregate impacts on the Russian economy as well as results specific to the telecommunications sector and other sectors of the economy. We first discuss the aggregate results, and then turn to the results for the telecommunications sector. In table 3, the welfare results are presented; we also present the assumed parameter values of policy variables and elasticities. In the subsequent tables we present results at the sector level on some key variables.

\section{Aggregate Welfare Effects of WTO Accession}

Combined Effects of All WTO Commitments. In table 3, we present medium term results for this scenario are in the column labeled "WTO." We estimate that the welfare gains to Russia are equal to 7.9 percent of Russian consumption (or 3.7 percent of GDP) in the medium term. ${ }^{23}$ These gains derive from three key effects: (1) improved access to the markets of non-CIS countries in selected products; (2) Russian tariff reduction; and (3) liberalization of barriers to foreign direct investment in services sectors. Wages of skilled labor, unskilled labor and rents paid to capital owners all increase.

\footnotetext{
${ }^{23}$ In Jensen, Rutherford and Tarr (2004a, 2004b) we estimate the welfare gains to 7.2 percent of Russian consumption. The difference is solely due to the update of the data on value-added in telecommunications, which increases the importance of telecommunications in the economy. In turn, this implies that the current barriers are more costly.
} 
Reduction of Barriers to FDI Only. In the column labeled "FDI only" we present the results of a scenario in which we simulate the impact of liberalizing barriers to FDI in all business services sectors in Russia, without lowering tariff barriers in goods markets or obtaining benefits of improved market access abroad. We can see that the overall gains to the economy from liberalization of barriers against FDI are 5.9 percent of consumption, or about 75 percent of the total gains. Thus, liberalization of the barriers to FDI is the key reform for Russia to achieve significant gains from WTO accession. Liberalization of barriers to FDI leads to an increase in the number of multinational firms providing business services in Russia that allows Russian firms to purchase quality adjusted units of business services more cheaply.

WTO Accession without Telecommunications. Here, we add a hypothetical scenario in which Russia joins the WTO with liberalization in all sectors with the exception of telecommunications. That is, in this scenario there is no reduction of barriers to FDI in telecommunications assumed, but all other aspects of the assumed accession to the WTO are included. The results are presented in the column labeled "WTO w/o Telecom." We find that the gains to Russia fall from 7.9 percent of consumption to 6.3 percent. Thus, the impact of taking telecommunications reform out of Russian WTO accession is a cost to the Russian economy in aggregate of about 1.6 percent of consumption. Returns to labor and capital fall proportionately. All of these scenarios are performed under that assumption the ad valorem equivalent of the barrier to FDI is conservatively estimated at 33 percent.

Telecommunications Only. We also consider the impact of unilateral liberalization of barriers to FDI in telecommunications, independent of any economy-wide reforms negotiated under WTO accession. The results for this scenario are in the column labeled "Telecom only." The gains to the economy are about 1.6 percent of consumption, the same as what we inferred as the gains to the economy from WTO without telecommunications reform. This corresponds to 27 percent of the gains from liberalization of the barriers in all services sectors and to 20 percent of 
the total gains from WTO accession. Returns to labor and capital increase by between 0.5 percent and 0.9 percent from telecommunications liberalization alone.

The gains are due to higher FDI, i.e., multinational service providers increase their presence in the Russian market and improve the availability of telecommunications services to Russian businesses and households. More and better telecommunication services lower the cost of doing business and increases the productivity of Russian firms, which is also to the benefit of the rest of the Russian economy.

More and better telecommunication services also make labor and capital more productive. Higher productivity leads to increased returns to capital and to higher wages. The latter effect applies to both skilled and unskilled labor. In other words, FDI liberalization benefits labor interests. We provide more intuition for this result below.

Telecommunications Only in the Steady State. In the column labeled "Telecom only, steady state," we evaluate the impact of unilateral liberalization of barriers to FDI in the telecommunications sector, all other things unchanged. The gains increase to 3.5 percent of consumption. The reason the steady state gains are larger than the comparative static gains is that the liberalization of barriers to FDI in telecom results in an increase in the economy-wide profitability of investment. In the steady state scenario, investment increases and the capital stock expands until the marginal productivity of capital declines sufficiently to restore the long run equilibrium in the profitability of investment. In Jensen, Rutherford and Tarr (2004b), we show that the steady state gains from WTO accession broadly are about three times the value of the estimated comparative static gains. We assess these steady state gains to be upper bound estimates of the long run gains in the context of the assumptions of this model, since the steady state scenario fails to adjust for the foregone consumption required to achieve the higher value of the capital stock. 


\section{Results for the Telecommunications Sector}

Results for all sectors of change in output, skilled employment, unskilled employment, and prices are presented in tables 4-8. Employment of skilled and unskilled labor tends to increase in the telecommunications sector when more multinational firms locate in Russia. The reason is as follows. As a result of a reduction in the barriers to foreign direct investment, we estimate that there will be an expansion in the number of multinational firms who locate in Russia to provide telecommunication services from within Russia, and a contraction in the number of purely Russian firms. Employment in purely Russian firms may therefore decrease, but multinationals also demand Russian labor, even though they use Russian labor less intensively than Russian firms.

As mentioned above, based on estimates from ZNIIS, we have estimated of the share of expatriate labor used by multinationals in telecommunications at 10 percent. As more telecommunications firms enter the market, the quality adjusted price of telecommunication services falls, and industries that use telecommunication services expand their quantity demanded of telecommunication services. Although the result is elasticity dependent, in all the scenarios we have discussed so far, on balance, the increase in the quantity demanded of Russian labor from the increase in the quantity demanded for telecommunication services exceeds the decline in labor demand from the substitution of multinational supply for Russian supply in the Russian market. Thus, full liberalization of barriers to foreign direct investment in telecommunications services in Russia either independently or within the context of WTO accession should benefit labor in the telecommunications sector.

Regarding capital, as a result of the removal of restrictions, we estimate there would be significant increase in foreign direct investment and an increase in multinational firms operating in Russia. Regarding Russian firms, we must be careful in interpreting what this means. Multinationals will often look for Russian joint venture partners when they want to invest in Russia. Many Russian companies providing telecommunication services are likely to see this as a 
profitable opportunity and form joint ventures with multinationals. According to our definition (any positive share of foreign ownership is a multinational) these companies will become part of the expanding multinational share of the telecommunications market. The wholly owned Russian firms that become part of joint ventures with foreign investors will likely preserve or increase the value of their investments. Russian capital owners in the telecommunication sector who remain wholly independent of multinational firms, either because they avoid joint ventures or are not desired as joint venture partners, will likely see the value of their investments decline. ${ }^{24}$ Since more competitive modern firms are likely to be most valued by foreign investors, Russian firms have increased incentive to modernize and become competitive. Restructuring may not only make Russian firms more efficient, it may also allow them to reap profits from joint venture investments in an environment with more foreign investment.

Prices vary by producer and user. Russian telecommunications producers experience a decline in the price they receive from between 10 percent and 13 percent due to the substitution toward multinationals. Multinational producers see an increase in their prices (exclusive of any possible rents they may have earned from the barriers to FDI) by about 10 percent to 14 percent due to the decline in barriers against multinational investment in telecommunications. Users of telecommunications services (both for final demand and intermediate demand) obtain a reduction in the quality-adjusted cost of purchasing telecommunications services by between 20 percent and 22 percent. The main reason for the decline in the quality-adjusted price of telecommunications services is that the quality-adjusted price is a decreasing function of the number of varieties. That is, the cost of a unit of telecommunications services decreases with the number of varieties ${ }^{25}$ :

$$
\mathrm{C}_{\mathrm{m}}=\mathrm{P}_{\mathrm{m}} / \mathrm{n}_{\mathrm{m}}^{(\mathrm{s}-1)} \quad \mathrm{C}_{\mathrm{R}}=\mathrm{P}_{\mathrm{R}} / \mathrm{n}_{\mathrm{R}}^{(\mathrm{s}-1)}
$$

\footnotetext{
${ }^{24}$ This suggests that domestic lobbying interests within the telecommunications sector could be diverse regarding FDI liberalization. Specific labor in the telecommunications sector may support FDI liberalization even if capital owners in the sector oppose it.

${ }^{25}$ See Markusen, Rutherford and Tarr (2000) for the details of the derivation.
} 
where $C_{m}$ is the user quality adjusted cost of multinational telecommunications services, $P_{m}$ is the producer price of multinational telecommunications services, $\mathrm{n}_{\mathrm{m}}$ is the number of multinational service providers and $\mathrm{s}$ is the elasticity of substitution between varieties, which must be larger than one for optimization; an analogous interpretation applies for $C_{R}$ the quality adjusted cost of purchasing a unit of Russian services. We have a value of $s=3$, so we have:

$$
\mathrm{C}_{\mathrm{m}}=\mathrm{P}_{\mathrm{m}} / \mathrm{n}_{\mathrm{m}}^{2} \quad \mathrm{C}_{\mathrm{R}}=\mathrm{P}_{\mathrm{R}} / \mathrm{n}_{\mathrm{R}}^{2}
$$

For Russian telecommunications firms the producer price falls by about 10 percent, but the number of wholly owned Russian firms falls by about 75 percent. For multinational telecommunications firms in Russia, the producer cost increases by about 14 percent, but the number of multinational varieties (starting from a small share) increases by about 435 percent. Thus, the user cost of multinational telecommunications services falls. The total user cost is an aggregate of the multinational and Russian costs, and is dominated by the large increase in the number of multinational varieties. Thus, the interest of users of telecommunications services (Russian business and households) is to see an expansion in foreign direct investment and multinational provision of telecommunication services in Russia.

\section{Sensitivity Analysis}

The results depend on the choice of parameters in the model. Many of these parameters are uncertain and it is therefore useful to evaluate the impact on the results of changing the values of the key parameters in the model. In Jensen, Rutherford and Tarr (2004a) we report the results of "piecemeal" sensitivity analysis of the parameters as well as systematic sensitivity analysis in which we randomly select parameters from their probability distributions and simulate the model 30,000 times. We find that very substantial welfare gains are preserved under a wide range of parameter choices. Here, we focus on the sensitivity with respect to key issues related to telecommunications: (i) the initial size of the barrier to FDI in the telecommunications sector; (ii) 
whether rents from these barriers are captured by Russian nationals and are therefore not lost to the economy of Russia or dissipated through wasteful lobbying activities; and (iii) the share of expatriate labor and specialized imported inputs used by multinational telecommunication services providers.

Ad Valorem Equivalence of the Barriers to Multinationals. Our central estimate of the barrier corresponds to a 33 percent ad valorem tax equivalent on multinationals. That is, the costs of multinational telecommunication services are 33 percent higher due to barriers to FDI. In our sensitivity analysis, we assume two alternative values for this barrier, namely 10 percent and 50 percent. We display the results for unilateral 100 percent elimination of these telecommunications barriers only in the columns labeled "Telecommunications only, low barriers," and "Telecommunications only, high barriers." We also analyze reductions of 25 percent in these barriers, but these results are not displayed in the tables.

The magnitude of the effects of liberalization depends heavily on the size of the initial barrier (as expected) (and on the size of the cuts in the barriers for the cases where we don't cut barriers by $100 \%$ ), but none of the qualitative conclusions change. That is, liberalization yields welfare gains to Russia for all values of the barriers and the larger the cut in the barrier the larger the gains. Very large gains of 2.8 percent of Russian consumption are derived from a 100 percent cut in the barriers to FDI in telecommunications alone, when the ad valorem barrier is assumed to be 50 percent instead of 33 percent. On the other hand, only a three-tenths of one percent gain is derived from a telecommunications only liberalization when the ad valorem barrier is assumed to be 10 percent instead of 33 percent The expansion of the demand for Russian labor and capital in the telecommunications sector is 10 percent with the removal of a 50 percent tax on telecommunications multinationals, but only 2 percent if the tax is 10 percent.

Rent Capture or Dissipation. If alternately, we assume that the ad valorem equivalence of the barriers to multinational investment uses Russian capital and labor in wasteful license seeking activities and the like, the costs to the economy of the barriers are higher. Economy-wide 
the gains from WTO accession increase from 7.9 percent to 8.7 percent of consumption and, in the case of telecommunications reform only, the gains increase from 1.6 percent to 1.9 percent of aggregate Russian consumption. Results at the level of telecommunications are not changed significantly.

Share of Expatriate Labor and Specialized Inputs Used by Multinationals. Although the aggregate welfare of Russia is not affected significantly by the share of expatriate labor used by multinational telecommunications services providers, employment in the Russia telecommunications sector is strongly affected by this parameter value.

A reduction in barriers to FDI leads to substitution of telecommunication services produced by purely Russian firms for services produced by multinationals. This substitution effect has an initial negative partial equilibrium effect on Russian labor and capital, as multinationals use these Russian factors of production less intensively than Russian firms. But there is also a scale effect, which has a positive effect on Russian labor and capital. The scale effect is due to the decrease in the quality-adjusted price of telecommunication services, which leads to an increase in the quantity demanded of quality-adjusted telecommunication services. Which effect is stronger on the demand for Russian labor, the substitution effect or the scale effect?

Based on ZNIIS estimates, in our central estimates we have assumed a value of 10 percent for the share of imported primary inputs in the multinationals, i.e., they use Russian labor and capital less intensively than Russian firms. We estimate that skilled labor employment in telecommunications will increase by 8 percent as a result of WTO accession and in a reform of telecommunications only employment of skilled telecommunications workers increases by 6 percent. If the share of imported primary inputs in the multinationals is 5 percent, 8 percent or 12 percent, our estimated increase in the demand for Russian skilled workers is 10 percent, 8 percent and 5 percent, respectively. Thus, as expected, the more multinationals use expatriate labor, the less the expansion of demand for Russian labor. 
Despite the fact that expatriate labor substitutes for Russian labor, an increase in multinational investment in telecommunications increases the demand for Russian labor in telecommunications for these parameter values. This repeats the result found in Markusen, Rutherford and Tarr (2000) that imported inputs are a partial equilibrium substitute for national labor but a general equilibrium complement.

\section{Conclusion}

These results show that reduction of barriers to foreign direct investment in telecommunications will bring substantial gains to the Russian economy, including an increase in the productivity of Russian labor and capital. Despite the fact that multinationals use Russian labor less intensively than Russian firms, demand for Russian labor employed in telecommunications should increase, especially if the reductions in barriers to FDI are included in the context of WTO accession. Russian capital owners in telecommunications will likely be sought as joint venture partners and can restructure and obtain gains as partners with foreign firms; wholly owned Russian firms are likely to experience losses. 


\section{References}

Baldwin, R.E. and J.F. Francois, eds.(1999), Dynamic Issue in Applied Commercial Policy Analysis, Cambridge University Press.

Baranov, S.P. (2000), "Compiling the disaggregated version of "input-output" tables of the Russian Federation for 1995 year for consequent use as a basic data for building the general equilibrium model for the Russian Federation." Available at: www.worldbank.org/russia-wto.

Barzel, Yoram (1974), “A Theory of Rationing by Waiting," The Journal of Law and Economics, 17, 73-95.

Brown, Drusilla, Alan Deardorf, Alan Fox and Robert Stern (1996), "Liberalization of Services Trade," in W. Martin and L. A. Winters, eds., The Uruguay Round and the Developing Countries, Cambridge: Cambridge University Press.

Brown, Drusilla and Robert Stern (2001), "Measurement and Modeling of the Economic Effects of Trade and Investment Barriers in Services," Review of International Economics, 9(2): 262-286.

Caballero, R. and R. Lyons (1992), "The Case for External Economies," in A. Cukierman, Z. Hercowitz and L. Leiderman, eds., Political Economy, Growth and Business Cycles, Cambridge, Massachusetts: MIT Press.

Chinitz, B. (1961), “Contrast in agglomeration: New York and Pittsburgh,” American Economic Review, Papers and Proceedings, 51:279-89.

Ciccone, A. and R. Hall (1996), "Productivity and the Density of Economic Activity," American Economic Review, 86(1):54-70.

Daniels, P.W. (1985), Service Industries: A Geographical Appraisal, New York: Methuen \& Co.

Dee, Philippa, Kevin Hanslow and Tien Phamduc (2003), "Measuring the Costs of Barriers to Trade in Services," in Takatoshi Ito and Anne Krueger (eds.), Trade in Services in the Asia-Pacific Region, Chicago: University of Chicago Press.

Dixit, A. and J. Stiglitz (1977), "Monopolistic Competition and Optimum Product Diversity," American Economic Review, 76(1):297-308.

Ethier, W.J. (1982), "National and International Returns to Scale in the Modern Theory of International Trade," American Economic Review, 72(2):389-405.

Findlay, Christopher and Tony Warren, eds. (2000), Impediments to Trade in Services: Measurement and Policy Implications, London: Routledge.

Francois, Joseph F. (1990a), "Trade in Producer Services and Returns due to Specialization under Monopolistic Competition”, Canadian Journal of Economics, 23:109-124. 
Francois, Joseph F. (1990b), "Producer Services, Scale, and the Division of Labor", Oxford Economic Papers, 42:715-729.

Fujita, Masahisa, Paul Krugman and Anthony J. Venables (1999), The Spatial Economy: Cities, Regions, and International Trade, Cambridge: MIT Press.

Goskomstat (2003a), Telecommunications and Post Services in Russia.

Goskomstat (2003b), Russia in Figures.

Harrison, Glenn, Thomas Rutherford and David Tarr (1997), "Quantifying the Uruguay Round," Economic Journal.

Hummels, D (1995), "Global Income Clustering and Trade in Intermediate Goods," Graduate School of Business, University of Chicago.

Jacobs, J. (1969), The Economy of Cities, New York: Random House.

Jacobs, J. (1984), Cities and the Wealth of Nations, New York: Random House.

Jensen, Jesper, Thomas Rutherford and David Tarr (2004a), "Economy-Wide and Sector Effects of Russia's Accession to the WTO." Available at: www.worldbank.org/russia-wto.

Jensen, Jesper, Thomas Rutherford and David Tarr (2004b), "The Impact of Liberalization of Barriers to Foreign Direct Investment in Services: The Case of Russian Accession to the WTO.” Available at: www.worldbank.org/russia-wto.

Kang, Joog-Soon (2000), "Price Impact of Restrictiveness on Maritime Transportation Services," in Findlay, Christopher and Tony Warren (eds), Impediments to Trade in Services: Measurement and Policy Implications, (London: Routledge).

Kimura, Fukunari, Mitsuyo Ando and Takamune Fujii (2004a), "Estimating the Ad Valorem Equivalent of Barriers to Foreign Direct Investment in the Telecommunications Services Sectors in Russia." Available at http://www.worldbank.org/trade/russia-wto.

Kimura, Fukunari, Mitsuyo Ando and Takamune Fujii (2004b), "Estimating the Ad Valorem Equivalent of Barriers to Foreign Direct Investment in the Maritime and Air Transportation Service Sectors in Russia." Available at http://www.worldbank.org/trade/russia-wto.

Kimura, Fukunari, Mitsuyo Ando and Takamune Fujii (2004c), "Estimating the Ad Valorem Equivalent of Barriers to Foreign Direct Investment in Financial Services Sectors in Russia." Available at http://www.worldbank.org/trade/russia-wto.

Kravis, I. And R. Lipsey (1988), "National Price Levels and the Prices of Tradables and Nontradables," American Economic Review, 78(May):474-8.

Krugman, P. (1991), Geography and Trade, Cambridge, Massachusetts: MIT Press. 
Markusen, James R. (1989), "Trade in Producer Services and in Other Specialized Intermediate Inputs," American Economic Review, 79:85-95.

Markusen, James R. (1990), "Derationalizing Tariffs with Specialized Intermediate Inputs and Differentiated Final Goods," Journal of International Economics, 28:375-384.

Markusen, James R, Thomas Rutherford and David Tarr (2000), Foreign Direct Investment in Services and the Domestic Market for Expertise," Policy and Reserach Working Paper 2413, Washington D.C.: The World Bank.

Marshall, J.N. (1988), Services and Uneven Development, London: Oxford University Press.

McGuire, Greg and Michael Schuele (2000), "Restrictiveness of International Trade in Banking Services," in Findlay, Christopher and Tony Warren (eds), Impediments to Trade in Services: Measurement and Policy Implications, (London: Routledge).

McKee, D.L. (1988), Growth, Development, and the Service Economy in the Third World, New York: Praeger Publishers.

Porter, M. (1992), The Competitive Advantage of Nations, New York: The Free Press.

Romer, Paul (1994), "New Goods, Old Theory and the Welfare Costs of Trade Restrictions," Journal of Development Economics," 43(1), February, 5-38.

Rutherford, Thomas F. and David Tarr (2002), "Trade Liberalization and Endogenous Growth in a Small Open Economy," Journal of International Economics.

Rutherford, Thomas F. (1999), "Applied General Equilibrium Modeling with MPSGE as a GAMS Subsystem: An Overview of the Modeling Framework and Syntax", Computational Economics.

Stanback, T.M. (1979), Understanding the Service Economy: Employment, Productivity and Location, Baltimore: Johns Hopkins University Press.

United Nations Conference on Trade and Development, Division on Transnational Corporations and Investment (1995 and 1996), World Investment Report 1995 and 1996, New York and Geneva: United Nations.

Vernon, R. (1960), Metropolis 1985, Cambridge: Harvard University Press.

Warren, Tony (2000), "The Impact on Output of Impediments to Trade and Investment in Telecommunications Services," in Findlay, Christopher and Tony Warren (eds), Impediments to Trade in Services: Measurement and Policy Implications, (London: Routledge).

Zemnitsky, Andrei (2001), "Non-tariff barriers in Russian services sectors," Part of Ph.D. dissertation at the Higher School of Economics, Moscow. 
Figure 1: Production and Allocation of Output

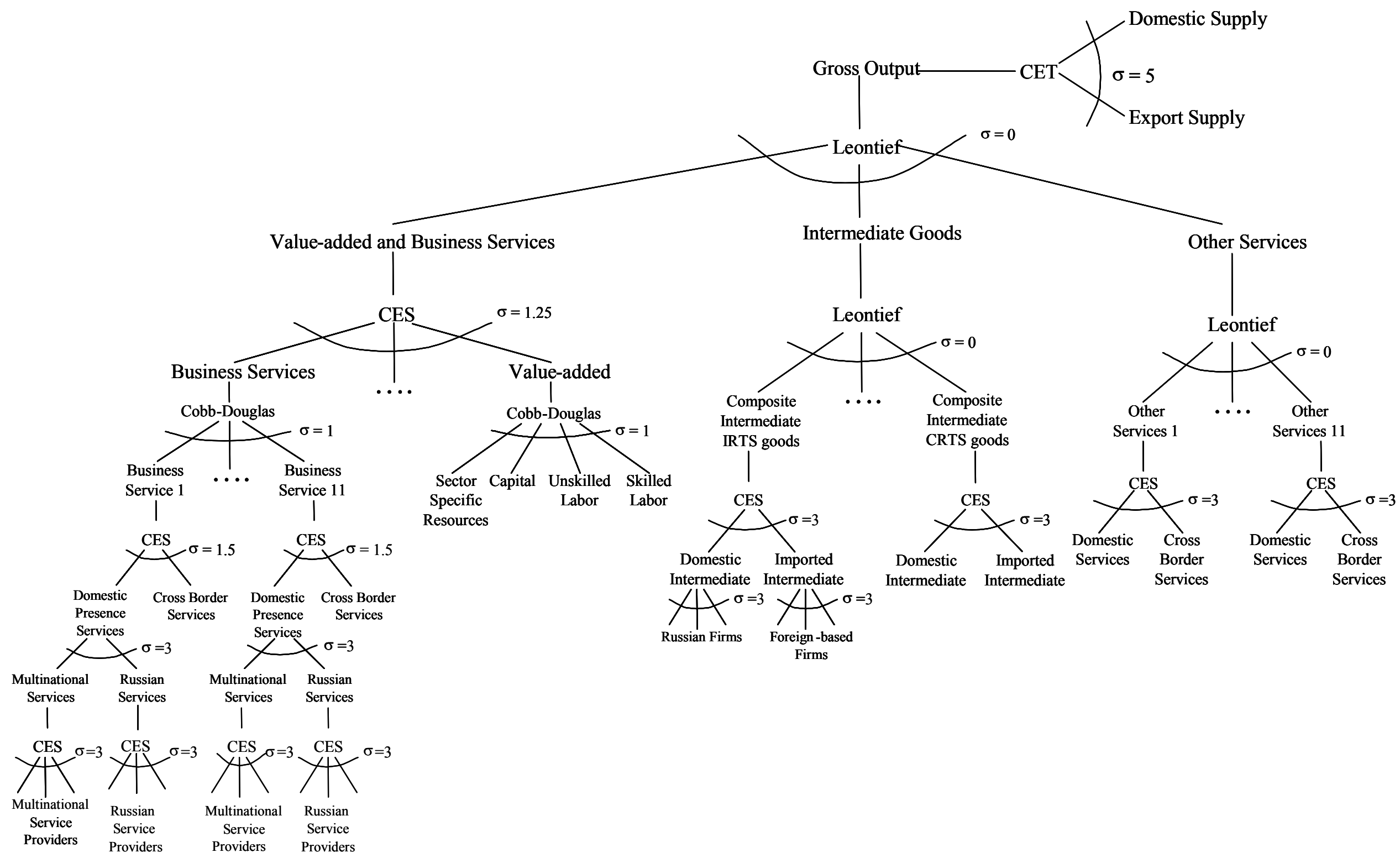


Table 1. List of Sectors

1. Sectors where foreign direct investment from new multinational services providers is possible

$\begin{array}{ll}\text { RLW } & \text { Railway transportation } \\ \text { TRK } & \text { Truck transportation } \\ \text { PIP } & \text { Pipelines transportation } \\ \text { MAR } & \text { Maritime transportation } \\ \text { AIR } & \text { Air transportation } \\ \text { TRO } & \text { Other transportation } \\ \text { TMS } & \text { Telecommunications } \\ \text { SCS } & \text { Science \& science servicing } \\ \text { SSM } & \text { Public health \& sports \& social security } \\ \text { ECM } & \text { Education \& culture \& art } \\ \text { FIN } & \text { Financial services }\end{array}$

\section{Sectors where new foreign firms may provide new goods from abroad}

FME Ferrous metallurgy

NFM Non-ferrous metallurgy

CHM Chemical \& oil-chemical industry

MWO Mechanical engineering \& metal-working

TPP Timber \& woodworking \& pulp \& paper industry

CNM Construction materials industry

CLO Light industry

FOO Food industry

OTH Other industries

\section{Competitive sectors subject to constant returns to scale}

$\begin{array}{ll}\text { ADM } & \text { Administration \& public associations } \\ \text { AGF } & \text { Agriculture \& forestry } \\ \text { COA } & \text { Coalmining } \\ \text { PSM } & \text { Communal \& consumer services } \\ \text { CON } & \text { Construction } \\ \text { ELE } & \text { Electric industry } \\ \text { GAS } & \text { Gas } \\ \text { GEO } & \text { Geology \& hydrometeorology } \\ \text { OLE } & \text { Oil extraction } \\ \text { OLP } & \text { Oil processing } \\ \text { OFU } & \text { Other fuel industries } \\ \text { OIN } & \text { Other goods-producing sectors } \\ \text { PST } & \text { Post } \\ \text { CAT } & \text { Public catering } \\ \text { TRD } & \text { Trade }\end{array}$


Table 2. Tariff Rates, Export Tax Rates, Estimated Ad Valorem Equivalence of Barriers to FDI in Services Sectors and Estimated Improved Market Access

(ad-valorem in \%) -- by sector

\begin{tabular}{|c|c|c|c|c|c|}
\hline & \multirow[b]{2}{*}{ Tariff rates } & \multirow{2}{*}{ Export tax rates } & \multirow{2}{*}{$\begin{array}{c}\text { Estimated } \\
\text { change in world } \\
\text { market price }\end{array}$} & \multicolumn{2}{|c|}{$\begin{array}{c}\text { Equivalent } \% \text { barriers to } \\
\text { FDI }\end{array}$} \\
\hline & & & & Base Year & $\begin{array}{l}\text { Post-WTO } \\
\text { Accession }\end{array}$ \\
\hline Electric industry & 4.5 & 0.0 & 0.0 & & \\
\hline Oil extraction & 0.0 & 7.9 & 0.0 & & \\
\hline Oil processing & 3.8 & 4.6 & 0.0 & & \\
\hline Gas & 0.5 & 18.8 & 0.0 & & \\
\hline Coalmining & 0.0 & 0.0 & 0.0 & & \\
\hline Other fuel industries & 2.6 & 2.6 & 0.0 & & \\
\hline Ferrous metallurgy & 2.9 & 0.4 & 1.5 & & \\
\hline Non-ferrous metallurgy & 7.4 & 5.3 & 1.5 & & \\
\hline Chemical \& oil-chemical industry & 7.1 & 1.6 & 1.5 & & \\
\hline Mechanical engineering \& metal-working & 7.2 & 0.0 & 0.0 & & \\
\hline Timber \& woodworking \& pulp \& paper industry & 9.9 & 6.9 & 0.0 & & \\
\hline Construction materials industry & 10.6 & 1.6 & 0.0 & & \\
\hline Light industry & 11.8 & 4.1 & 0.5 & & \\
\hline Food industry & 11.3 & 3.1 & 0.5 & & \\
\hline Other industries & 6.4 & 0.0 & 0.5 & & \\
\hline Agriculture \& forestry & 8.2 & 0.6 & 0.0 & & \\
\hline Other goods-producing sectors & 0.0 & 0.0 & 0.5 & & \\
\hline Telecommunications & & & & 33.0 & 0.0 \\
\hline Science \& science servicing (market) & & & & 33.0 & 0.0 \\
\hline Financial services & & & & 36.0 & 0.0 \\
\hline Railway transportation & & & & 33.0 & 0.0 \\
\hline Truck transportation & & & & 33.0 & 0.0 \\
\hline Pipelines transportation & & & & 33.0 & 0.0 \\
\hline Maritime transportation & & & & 95.0 & 80.0 \\
\hline Air transportation & & & & 90.0 & 75.0 \\
\hline Other transportation & & & & 33.0 & 0.0 \\
\hline
\end{tabular}


Table 3.

\begin{tabular}{|c|c|c|c|c|c|c|c|c|c|c|}
\hline \multirow[t]{2}{*}{ Scenarios and scenario definitions } & \multirow{2}{*}{ WTO } & \multirow{2}{*}{$\begin{array}{l}\text { WTO w/o } \\
\text { Telecom }\end{array}$} & \multirow{2}{*}{$\begin{array}{l}\text { Only FDI } \\
\text { Reform }\end{array}$} & \multirow{2}{*}{$\begin{array}{l}\text { Telecom } \\
\text { only }\end{array}$} & \multirow{2}{*}{$\begin{array}{l}\text { Telecom } \\
\text { only } \\
\text { Steady } \\
\text { State }\end{array}$} & \multicolumn{2}{|c|}{ To FDI in Telecom } & \multirow{2}{*}{$\begin{array}{l}\text { Low imported } \\
\text {-input share by } \\
\text { multinationals }\end{array}$} & \multirow{2}{*}{$\begin{array}{c}\text { WTO, } \\
\text { domestic } \\
\text { rent dissip. }\end{array}$} & \multirow{2}{*}{$\begin{array}{l}\text { Telecom, } \\
\text { domestic } \\
\text { rent dissip. }\end{array}$} \\
\hline & & & & & & Low barrier & High barrier & & & \\
\hline Reduction in barriers to FDI in telecom & $100 \%$ & & $100 \%$ & $100 \%$ & $100 \%$ & $100 \%$ & $100 \%$ & $100 \%$ & $100 \%$ & $100 \%$ \\
\hline Benchmark barriers to FDI in telecom (ad valorem equiv.) & $33 \%$ & $33 \%$ & $33 \%$ & $33 \%$ & $33 \%$ & $10 \%$ & $50 \%$ & $33 \%$ & $33 \%$ & $33 \%$ \\
\hline Benchmark FDI share of telecom market & $15 \%$ & $15 \%$ & $15 \%$ & $15 \%$ & $15 \%$ & $15 \%$ & $15 \%$ & $15 \%$ & $15 \%$ & $15 \%$ \\
\hline Share of imported inputs in telecom by multinationals & $10 \%$ & $10 \%$ & $10 \%$ & $10 \%$ & $10 \%$ & $10 \%$ & $10 \%$ & $5 \%$ & $10 \%$ & $10 \%$ \\
\hline General FDI reform & Yes & Yes & Yes & No & No & No & No & No & Yes & No \\
\hline Improved market access & Yes & Yes & No & No & No & No & No & No & Yes & No \\
\hline Percentage reduction in tariffs & $50 \%$ & $50 \%$ & $100 \%$ & $100 \%$ & $100 \%$ & $100 \%$ & $100 \%$ & $100 \%$ & $50 \%$ & $100 \%$ \\
\hline Rents dissipated using domestic resources & No & No & No & No & No & No & No & No & Yes & Yes \\
\hline Steady state model & No & No & No & No & Yes & No & No & No & No & No \\
\hline \multicolumn{11}{|l|}{ Summary results ( $\%$ change) } \\
\hline Equivalent variation relative to consumption & 7.9 & 6.3 & 5.9 & 1.6 & 3.5 & 0.3 & 2.8 & 1.5 & 8.7 & 1.9 \\
\hline Equivalent variation relative to GDP & 3.7 & 2.9 & 2.8 & 0.7 & 1.7 & 0.1 & 1.3 & 0.7 & 4.1 & 0.9 \\
\hline Exports & 14.2 & 13.5 & 3.8 & 0.7 & 1.8 & 0.2 & 1.0 & 0.4 & 14.6 & 0.8 \\
\hline Imports & 22.1 & 20.9 & 5.9 & 1.0 & 2.8 & 0.3 & 1.5 & 0.7 & 22.6 & 1.3 \\
\hline Factor income - capital & 6.6 & 5.5 & 3.8 & 0.9 & 0.6 & 0.2 & 1.6 & 0.9 & 6.5 & 0.9 \\
\hline Factor income - unskilled labor & 2.7 & 2.1 & 2.1 & 0.5 & 1.8 & 0.1 & 0.8 & 0.5 & 3.0 & 0.7 \\
\hline Factor income - skilled labor & 4.9 & 4.1 & 2.7 & 0.7 & 2.2 & 0.2 & 1.1 & 0.7 & 5.3 & 0.9 \\
\hline Tariff revenue & -34.0 & -34.7 & 9.6 & 4.8 & 7.5 & 3.8 & 5.8 & 4.8 & -33.8 & 4.9 \\
\hline Tariff revenue (as \% of GDP) & 0.9 & 0.8 & 1.4 & 1.4 & 1.4 & 1.3 & 1.4 & 1.4 & 0.9 & 1.4 \\
\hline Factor market adjustment - unskilled labor & 2.8 & 2.4 & 1.9 & 0.7 & 0.9 & 0.1 & 1.1 & 0.7 & 2.8 & 0.7 \\
\hline Factor market adjustment - skilled labor & 2.3 & 1.8 & 1.7 & 0.5 & 0.4 & 0.1 & 0.8 & 0.5 & 2.4 & 0.5 \\
\hline Factor market adjustment - capital & 0.6 & 0.6 & 0.2 & 0.0 & 0.0 & 0.0 & 0.1 & 0.1 & 0.6 & 0.0 \\
\hline Real exchange rate & 2.7 & 2.2 & 1.2 & 0.5 & 0.7 & 0.1 & 0.7 & 0.4 & 2.8 & 0.5 \\
\hline \multicolumn{11}{|l|}{ Model parameters - elasticities } \\
\hline Foreign firm supply wrt. price & 15.0 & 15.0 & 15.0 & 15.0 & 15.0 & 15.0 & 15.0 & 15.0 & 15.0 & 15.0 \\
\hline Domestic firm supply wrt. price & 7.5 & 7.5 & 7.5 & 7.5 & 7.5 & 7.5 & 7.5 & 7.5 & 7.5 & 7.5 \\
\hline Between domestic output and exports & 5.0 & 5.0 & 5.0 & 5.0 & 5.0 & 5.0 & 5.0 & 5.0 & 5.0 & 5.0 \\
\hline Between aggregate services and value-added & 1.25 & 1.25 & 1.25 & 1.25 & 1.25 & 1.25 & 1.25 & 1.25 & 1.25 & 1.25 \\
\hline Between goods varieties & 3.0 & 3.0 & 3.0 & 3.0 & 3.0 & 3.0 & 3.0 & 3.0 & 3.0 & 3.0 \\
\hline Between service varieties & 3.0 & 3.0 & 3.0 & 3.0 & 3.0 & 3.0 & 3.0 & 3.0 & 3.0 & 3.0 \\
\hline Between imported and domestic goods & 3.0 & 3.0 & 3.0 & 3.0 & 3.0 & 3.0 & 3.0 & 3.0 & 3.0 & 3.0 \\
\hline Between cross-border and domestic presence services & 1.5 & 1.50 & 1.5 & 1.5 & 1.5 & 1.5 & 1.5 & 1.5 & 1.5 & 1.5 \\
\hline
\end{tabular}


Table 4.

\begin{tabular}{|c|c|c|c|c|c|c|c|c|c|c|}
\hline \multirow[t]{2}{*}{ Scenarios and scenario definitions } & \multirow{2}{*}{ WTO } & \multirow{2}{*}{$\begin{array}{l}\text { WTO w/o } \\
\text { Telecom }\end{array}$} & \multirow{2}{*}{$\begin{array}{l}\text { Only FDI } \\
\text { Reform }\end{array}$} & \multirow{2}{*}{$\begin{array}{c}\text { Telecom } \\
\text { only }\end{array}$} & \multirow{2}{*}{$\begin{array}{l}\text { Telecom } \\
\text { only } \\
\text { Steady } \\
\text { State } \\
\end{array}$} & \multicolumn{2}{|c|}{ To FDI in Telecom } & \multirow{2}{*}{$\begin{array}{l}\text { Low imported } \\
\text { - input share by } \\
\text { multinationals }\end{array}$} & \multirow{2}{*}{$\begin{array}{c}\text { WTO, } \\
\text { domestic } \\
\text { rent dissip. }\end{array}$} & \multirow{2}{*}{$\begin{array}{c}\text { Telecom, } \\
\text { domestic } \\
\text { rent dissip. }\end{array}$} \\
\hline & & & & & & Low barrier & High barrier & & & \\
\hline \multicolumn{11}{|l|}{ Aggregate output (\% change) } \\
\hline Electric industry & 2.3 & 1.6 & 1.8 & 0.7 & 1.4 & 0.1 & 1.1 & 0.6 & 2.5 & 0.8 \\
\hline Oil extraction & 3.2 & 2.5 & 3.4 & 0.7 & 0.7 & 0.1 & 1.1 & 0.6 & 3.3 & 0.7 \\
\hline Oil processing & 2.3 & 1.2 & 3.5 & 1.1 & 2.2 & 0.2 & 1.8 & 1.0 & 2.7 & 1.2 \\
\hline Gas & 3.6 & 3.1 & 5.4 & 0.4 & 1.3 & 0.1 & 0.7 & 0.4 & 3.9 & 0.5 \\
\hline Coalmining & 6.4 & 5.8 & 3.9 & 0.5 & 0.7 & 0.1 & 0.9 & 0.4 & 6.5 & 0.6 \\
\hline Other fuel industries & 1.6 & 1.0 & 2.6 & 0.6 & 1.7 & 0.1 & 0.9 & 0.5 & 1.8 & 0.7 \\
\hline Ferrous metallurgy & 15.5 & 15.5 & 4.0 & 0.0 & -0.2 & 0.0 & 0.0 & -0.2 & 15.4 & 0.0 \\
\hline Non-ferrous metallurgy & 24.3 & 25.6 & -11.1 & -1.1 & 3.0 & -0.2 & -2.1 & -1.6 & 25.7 & -0.6 \\
\hline Chemical \& oil-chemical industry & 10.5 & 9.8 & 3.3 & 0.5 & 0.8 & 0.1 & 0.8 & 0.3 & 10.6 & 0.6 \\
\hline Mechanical engineering \& metal-working & -11.2 & -12.4 & 1.9 & 1.2 & 1.1 & 0.3 & 1.9 & 1.0 & -11.3 & 1.2 \\
\hline Timber \& woodworking \& pulp \& paper industry & -1.6 & -3.3 & 6.3 & 1.5 & 1.6 & 0.3 & 2.4 & 1.2 & -1.5 & 1.5 \\
\hline Construction materials industry & -5.9 & -6.2 & 0.9 & 0.3 & 1.3 & 0.1 & 0.4 & 0.2 & -5.9 & 0.3 \\
\hline Light industry & -6.3 & -8.3 & 2.4 & 2.1 & 1.4 & 0.4 & 3.5 & 1.9 & -6.4 & 2.1 \\
\hline Food industry & -13.5 & -13.9 & 0.8 & 0.5 & 1.8 & 0.1 & 0.8 & 0.4 & -13.2 & 0.7 \\
\hline Other industries & -4.6 & -5.8 & 2.1 & 1.0 & 1.6 & 0.2 & 1.7 & 0.9 & -4.4 & 1.1 \\
\hline Construction & 0.4 & 0.3 & 0.3 & 0.1 & 1.8 & 0.0 & 0.2 & 0.1 & 0.4 & 0.1 \\
\hline Agriculture \& forestry & -2.2 & -2.9 & 2.4 & 0.7 & 2.2 & 0.1 & 1.2 & 0.6 & -1.7 & 0.9 \\
\hline Railway transportation & 0.9 & 0.1 & -0.3 & 0.7 & 1.6 & 0.1 & 1.2 & 0.6 & 1.1 & 0.8 \\
\hline Truck transportation & 8.8 & 7.1 & 7.2 & 1.5 & 2.7 & 0.3 & 2.5 & 1.4 & 9.1 & 1.7 \\
\hline Pipelines transportation & -4.7 & -5.0 & -3.2 & 0.3 & 1.1 & 0.1 & 0.5 & 0.3 & -4.5 & 0.4 \\
\hline Maritime transportation & 5.3 & 1.8 & 0.7 & 2.9 & 3.7 & 0.6 & 4.8 & 2.6 & 5.5 & 3.0 \\
\hline Air transportation & 1.9 & -3.1 & 0.7 & 4.9 & 5.7 & 1.0 & 8.5 & 4.8 & 2.3 & 5.1 \\
\hline Other transportation & 4.0 & 2.7 & 3.3 & 1.2 & 2.4 & 0.2 & 2.0 & 1.1 & 4.4 & 1.4 \\
\hline Telecommunications & 8.3 & 1.9 & 8.5 & 6.1 & 7.3 & 1.7 & 9.9 & 10.0 & 8.7 & 6.3 \\
\hline Post & 4.8 & 1.1 & 5.2 & 3.7 & 5.0 & 0.7 & 6.4 & 3.7 & 5.2 & 3.9 \\
\hline Trade & 6.0 & 5.3 & 3.8 & 0.7 & 2.2 & 0.1 & 1.2 & 0.6 & 6.5 & 0.9 \\
\hline Public catering & 6.5 & 5.4 & 4.5 & 1.0 & 2.6 & 0.2 & 1.8 & 1.0 & 7.1 & 1.3 \\
\hline Other goods-producing sectors & -0.3 & -1.5 & 3.0 & 1.2 & 1.8 & 0.2 & 2.0 & 1.1 & -0.1 & 1.3 \\
\hline Communal \& consumer services (market) & 2.4 & 1.7 & 2.2 & 0.6 & 1.6 & 0.1 & 1.1 & 0.6 & 2.7 & 0.8 \\
\hline Public health \& sports \& social security (mar & 0.8 & 0.6 & 0.6 & 0.2 & 0.4 & 0.0 & 0.3 & 0.2 & 0.9 & 0.2 \\
\hline Education \& culture \& art (market) & 0.6 & 0.4 & 0.5 & 0.2 & 0.3 & 0.0 & 0.3 & 0.2 & 0.6 & 0.2 \\
\hline Science \& science servicing (market) & -10.4 & -11.4 & -10.7 & 0.9 & 1.0 & 0.2 & 1.6 & 0.9 & -10.4 & 0.9 \\
\hline Geology \& hydrometeorology & 0.1 & 0.1 & 0.1 & 0.0 & 1.7 & 0.0 & 0.0 & 0.0 & 0.1 & 0.0 \\
\hline Financial services & 9.0 & 6.6 & 9.3 & 2.1 & 3.0 & 0.4 & 3.6 & 2.1 & 9.3 & 2.3 \\
\hline Administration \& public associations (market) & 0.6 & 0.4 & 0.5 & 0.1 & 0.2 & 0.0 & 0.2 & 0.1 & 0.6 & 0.1 \\
\hline
\end{tabular}


Table 5.

\begin{tabular}{|c|c|c|c|c|c|c|c|c|c|c|}
\hline \multirow[t]{2}{*}{ Scenarios and scenario definitions } & \multirow{2}{*}{ WTO } & \multirow{2}{*}{$\begin{array}{l}\text { WTO w/o } \\
\text { Telecom }\end{array}$} & \multirow{2}{*}{$\begin{array}{l}\text { Only FDI } \\
\text { Reform }\end{array}$} & \multirow{2}{*}{$\begin{array}{c}\text { Telecom } \\
\text { only }\end{array}$} & \multirow{2}{*}{$\begin{array}{l}\text { Telecom } \\
\text { only } \\
\text { Steady } \\
\text { State } \\
\end{array}$} & \multicolumn{2}{|c|}{ To FDI in Telecom } & \multirow{2}{*}{$\begin{array}{l}\text { Low imported } \\
\text { - input share by } \\
\text { multinationals }\end{array}$} & \multirow{2}{*}{$\begin{array}{l}\text { WTO, } \\
\text { domestic } \\
\text { rent dissip. }\end{array}$} & \multirow{2}{*}{$\begin{array}{l}\text { Telecom, } \\
\text { domestic } \\
\text { rent dissip. }\end{array}$} \\
\hline & & & & & & Low barrier & High barrier & & & \\
\hline \multicolumn{11}{|l|}{ Skilled employment (\% change) } \\
\hline Electric industry & 2.1 & 1.5 & 1.6 & 0.6 & 0.1 & 0.1 & 1.0 & 0.5 & 2.1 & 0.6 \\
\hline Oil extraction & 1.1 & 0.6 & 2.3 & 0.5 & -0.4 & 0.1 & 0.7 & 0.3 & 1.0 & 0.4 \\
\hline Oil processing & 2.7 & 1.5 & 3.5 & 1.1 & 0.8 & 0.2 & 1.8 & 1.0 & 2.7 & 1.1 \\
\hline Gas & 15.8 & 14.2 & 28.5 & 1.3 & 6.4 & 0.4 & 1.9 & 0.9 & 17.2 & 2.0 \\
\hline Coalmining & 6.0 & 5.8 & 2.6 & 0.3 & 0.1 & 0.1 & 0.4 & 0.1 & 6.0 & 0.3 \\
\hline Other fuel industries & 1.5 & 1.1 & 2.7 & 0.4 & 0.2 & 0.1 & 0.7 & 0.3 & 1.5 & 0.4 \\
\hline Ferrous metallurgy & 14.9 & 15.1 & 3.4 & -0.1 & -1.5 & 0.0 & -0.2 & -0.3 & 14.5 & -0.2 \\
\hline Non-ferrous metallurgy & 23.9 & 25.3 & -11.5 & -1.2 & 1.6 & -0.2 & -2.2 & -1.7 & 24.9 & -0.8 \\
\hline Chemical \& oil-chemical industry & 8.8 & 8.5 & 1.9 & 0.2 & -0.7 & 0.0 & 0.3 & 0.0 & 8.6 & 0.1 \\
\hline Mechanical engineering \& metal-working & -13.0 & -13.6 & 0.5 & 0.6 & -0.3 & 0.1 & 1.0 & 0.4 & -13.2 & 0.5 \\
\hline Timber \& woodworking \& pulp \& paper industry & -3.4 & -4.6 & 4.7 & 1.0 & 0.1 & 0.2 & 1.6 & 0.7 & -3.5 & 0.9 \\
\hline Construction materials industry & -7.2 & -7.1 & -0.2 & -0.1 & -0.2 & 0.0 & -0.1 & -0.2 & -7.3 & -0.2 \\
\hline Light industry & -8.7 & -9.9 & 0.6 & 1.2 & -0.3 & 0.2 & 2.0 & 1.0 & -9.0 & 1.1 \\
\hline Food industry & -14.7 & -14.8 & -0.4 & 0.1 & 0.2 & 0.0 & 0.3 & 0.0 & -14.6 & 0.2 \\
\hline Other industries & -7.3 & -7.2 & -0.1 & -0.3 & -0.4 & -0.1 & -0.5 & -0.4 & -7.2 & -0.3 \\
\hline Construction & -1.1 & -0.8 & -0.9 & -0.2 & 0.5 & -0.1 & -0.3 & -0.2 & -1.2 & -0.3 \\
\hline Agriculture \& forestry & -2.3 & -2.8 & 2.3 & 0.6 & 0.7 & 0.1 & 1.0 & 0.5 & -2.1 & 0.7 \\
\hline Railway transportation & 0.5 & -0.1 & -0.4 & 0.6 & 0.5 & 0.1 & 0.9 & 0.5 & 0.5 & 0.6 \\
\hline Truck transportation & 7.3 & 6.4 & 6.0 & 0.8 & 1.2 & 0.1 & 1.4 & 0.7 & 7.5 & 0.9 \\
\hline Pipelines transportation & -4.1 & -4.2 & -3.0 & 0.1 & -0.9 & 0.0 & 0.1 & 0.0 & -4.3 & 0.0 \\
\hline Maritime transportation & 1.2 & -1.2 & -2.8 & 2.0 & 1.7 & 0.4 & 3.3 & 1.7 & 1.2 & 2.0 \\
\hline Air transportation & -3.6 & -5.2 & -4.1 & 1.6 & 1.6 & 0.3 & 2.8 & 1.4 & -3.3 & 1.7 \\
\hline Other transportation & 2.8 & 2.2 & 2.2 & 0.5 & 0.6 & 0.1 & 1.0 & 0.5 & 2.9 & 0.6 \\
\hline Telecommunications & 7.7 & 1.3 & 8.2 & 6.2 & 6.2 & 1.7 & 9.9 & 10.0 & 7.8 & 6.3 \\
\hline Post & -0.5 & 0.6 & -0.1 & -1.0 & -1.1 & -0.3 & -1.5 & -1.0 & -0.4 & -1.0 \\
\hline Trade & 4.8 & 4.6 & 2.4 & 0.3 & 0.2 & 0.0 & 0.5 & 0.1 & 4.9 & 0.3 \\
\hline Public catering & 1.3 & 1.6 & 0.5 & -0.2 & 0.9 & -0.1 & -0.3 & -0.3 & 1.9 & 0.0 \\
\hline Other goods-producing sectors & -3.3 & -3.2 & 0.9 & -0.1 & 0.1 & 0.0 & -0.2 & -0.2 & -3.1 & 0.0 \\
\hline Communal \& consumer services (market) & 2.1 & 1.7 & 1.9 & 0.4 & 0.1 & 0.1 & 0.7 & 0.4 & 2.2 & 0.4 \\
\hline Public health \& sports \& social security (mar & -1.5 & -0.9 & -0.9 & -0.6 & -1.2 & -0.1 & -1.0 & -0.6 & -1.6 & -0.6 \\
\hline Education \& culture \& art (market) & -2.0 & -0.9 & -1.3 & -1.1 & -1.7 & -0.2 & -1.8 & -1.1 & -2.1 & -1.1 \\
\hline Science \& science servicing (market) & -13.3 & -12.5 & -13.0 & -1.0 & -1.8 & -0.2 & -1.7 & -1.0 & -13.4 & -1.1 \\
\hline Geology \& hydrometeorology & -3.4 & -2.1 & -2.6 & -1.3 & -0.5 & -0.3 & -2.2 & -1.3 & -3.6 & -1.4 \\
\hline Financial services & 5.0 & 5.8 & 5.7 & -0.8 & -0.8 & -0.2 & -1.2 & -0.8 & 5.1 & -0.7 \\
\hline Administration \& public associations (market) & -8.9 & -6.4 & -8.2 & -2.5 & -3.2 & -0.6 & -4.1 & -2.5 & -9.0 & -2.6 \\
\hline
\end{tabular}


Table 6.

\begin{tabular}{|c|c|c|c|c|c|c|c|c|c|c|}
\hline \multirow[t]{2}{*}{ Scenarios and scenario definitions } & \multirow{2}{*}{ WTO } & \multirow{2}{*}{$\begin{array}{l}\text { WTO w/o } \\
\text { Telecom }\end{array}$} & \multirow{2}{*}{$\begin{array}{l}\text { Only FDI } \\
\text { Reform }\end{array}$} & \multirow{2}{*}{$\begin{array}{l}\text { Telecom } \\
\text { only }\end{array}$} & \multirow{2}{*}{$\begin{array}{c}\text { Telecom } \\
\text { only } \\
\text { Steady } \\
\text { State }\end{array}$} & \multicolumn{2}{|c|}{ To FDI in Telecom } & \multirow{2}{*}{$\begin{array}{l}\text { Low imported } \\
\text {-input share by } \\
\text { multinationals }\end{array}$} & \multirow{2}{*}{$\begin{array}{c}\text { WTO, } \\
\text { domestic } \\
\text { rent dissip. }\end{array}$} & \multirow{2}{*}{$\begin{array}{c}\text { Telecom, } \\
\text { domestic } \\
\text { rent dissip. }\end{array}$} \\
\hline & & & & & & Low barrier & High barrier & & & \\
\hline \multicolumn{11}{|l|}{ Unskilled employment (\% change) } \\
\hline Electric industry & 4.3 & 3.5 & 2.2 & 0.8 & 0.5 & 0.2 & 1.2 & 0.7 & 4.3 & 0.7 \\
\hline Oil extraction & 3.3 & 2.6 & 2.9 & 0.6 & 0.0 & 0.1 & 1.0 & 0.5 & 3.2 & 0.6 \\
\hline Oil processing & 4.9 & 3.6 & 4.1 & 1.3 & 1.2 & 0.3 & 2.1 & 1.2 & 4.9 & 1.3 \\
\hline Gas & 18.4 & 16.4 & 29.3 & 1.5 & 6.8 & 0.4 & 2.3 & 1.1 & 19.8 & 2.2 \\
\hline Coalmining & 8.3 & 7.9 & 3.2 & 0.4 & 0.5 & 0.1 & 0.7 & 0.3 & 8.4 & 0.5 \\
\hline Other fuel industries & 3.8 & 3.1 & 3.3 & 0.6 & 0.6 & 0.1 & 1.0 & 0.5 & 3.7 & 0.6 \\
\hline Ferrous metallurgy & 17.4 & 17.3 & 4.1 & 0.1 & -1.1 & 0.0 & 0.1 & -0.1 & 17.0 & 0.0 \\
\hline Non-ferrous metallurgy & 26.6 & 27.8 & -11.0 & -1.0 & 2.1 & -0.1 & -1.9 & -1.5 & 27.6 & -0.6 \\
\hline Chemical \& oil-chemical industry & 11.2 & 10.7 & 2.5 & 0.4 & -0.3 & 0.1 & 0.6 & 0.2 & 11.0 & 0.3 \\
\hline Mechanical engineering \& metal-working & -11.1 & -11.9 & 1.1 & 0.8 & 0.1 & 0.2 & 1.3 & 0.6 & -11.3 & 0.7 \\
\hline Timber \& woodworking \& pulp \& paper industry & -1.3 & -2.7 & 5.3 & 1.2 & 0.6 & 0.3 & 1.9 & 0.9 & -1.4 & 1.1 \\
\hline Construction materials industry & -5.2 & -5.3 & 0.4 & 0.1 & 0.2 & 0.0 & 0.1 & 0.0 & -5.3 & 0.0 \\
\hline Light industry & -6.7 & -8.1 & 1.2 & 1.4 & 0.1 & 0.3 & 2.3 & 1.2 & -7.0 & 1.3 \\
\hline Food industry & -12.8 & -13.1 & 0.2 & 0.3 & 0.6 & 0.1 & 0.6 & 0.2 & -12.7 & 0.4 \\
\hline Other industries & -5.3 & -5.3 & 0.5 & -0.1 & 0.0 & 0.0 & -0.2 & -0.2 & -5.2 & -0.1 \\
\hline Construction & 1.1 & 1.1 & -0.3 & 0.0 & 0.9 & 0.0 & 0.0 & 0.0 & 0.9 & -0.1 \\
\hline Agriculture \& forestry & -0.2 & -0.9 & 2.9 & 0.7 & 1.1 & 0.1 & 1.3 & 0.7 & 0.1 & 0.9 \\
\hline Railway transportation & 2.7 & 1.9 & 0.2 & 0.7 & 0.9 & 0.2 & 1.2 & 0.7 & 2.7 & 0.8 \\
\hline Truck transportation & 9.6 & 8.5 & 6.7 & 1.0 & 1.6 & 0.2 & 1.7 & 0.9 & 9.8 & 1.1 \\
\hline Pipelines transportation & -2.0 & -2.3 & -2.5 & 0.3 & -0.5 & 0.1 & 0.4 & 0.2 & -2.2 & 0.2 \\
\hline Maritime transportation & 3.4 & 0.8 & -2.2 & 2.2 & 2.1 & 0.5 & 3.6 & 1.9 & 3.4 & 2.2 \\
\hline Air transportation & -1.5 & -3.3 & -3.5 & 1.7 & 2.0 & 0.3 & 3.1 & 1.6 & -1.2 & 1.9 \\
\hline Other transportation & 5.0 & 4.2 & 2.8 & 0.7 & 1.0 & 0.1 & 1.2 & 0.7 & 5.1 & 0.8 \\
\hline Telecommunications & 10.0 & 3.3 & 8.8 & 6.4 & 6.7 & 1.8 & 10.3 & 10.3 & 10.2 & 6.5 \\
\hline Post & 1.6 & 2.6 & 0.5 & -0.8 & -0.7 & -0.2 & -1.2 & -0.8 & 1.8 & -0.8 \\
\hline Trade & 7.1 & 6.7 & 3.0 & 0.4 & 0.6 & 0.1 & 0.8 & 0.3 & 7.2 & 0.5 \\
\hline Public catering & 3.5 & 3.6 & 1.1 & -0.1 & 1.3 & -0.1 & 0.0 & -0.1 & 4.1 & 0.2 \\
\hline Other goods-producing sectors & -1.2 & -1.3 & 1.5 & 0.1 & 0.6 & 0.0 & 0.1 & 0.0 & -1.0 & 0.2 \\
\hline Communal \& consumer services (market) & 4.3 & 3.7 & 2.5 & 0.6 & 0.5 & 0.1 & 1.0 & 0.6 & 4.4 & 0.6 \\
\hline Public health \& sports \& social security (mar & 0.6 & 1.1 & -0.3 & -0.4 & -0.8 & -0.1 & -0.7 & -0.4 & 0.6 & -0.4 \\
\hline Education \& culture \& art (market) & 0.1 & 1.0 & -0.7 & -0.9 & -1.3 & -0.2 & -1.5 & -0.9 & 0.0 & -0.9 \\
\hline Science \& science servicing (market) & -11.4 & -10.8 & -12.5 & -0.8 & -1.4 & -0.2 & -1.4 & -0.8 & -11.6 & -0.9 \\
\hline Geology \& hydrometeorology & -1.3 & -0.1 & -2.0 & -1.1 & -0.1 & -0.2 & -1.9 & -1.1 & -1.5 & -1.2 \\
\hline Financial services & 7.3 & 7.9 & 6.3 & -0.6 & -0.4 & -0.1 & -0.9 & -0.6 & 7.4 & -0.5 \\
\hline Administration \& public associations (market) & -6.9 & -4.5 & -7.6 & -2.4 & -2.8 & -0.5 & -3.9 & -2.4 & -7.0 & -2.4 \\
\hline
\end{tabular}


Table 7.

\begin{tabular}{|c|c|c|c|c|c|c|c|c|c|c|}
\hline \multirow[t]{2}{*}{ Scenarios and scenario definitions } & \multirow{2}{*}{ WTO } & \multirow{2}{*}{$\begin{array}{l}\text { WTO w/o } \\
\text { Telecom }\end{array}$} & \multirow{2}{*}{$\begin{array}{l}\text { Only FDI } \\
\text { Reform }\end{array}$} & \multirow{2}{*}{$\begin{array}{c}\text { Telecom } \\
\text { only }\end{array}$} & \multirow{2}{*}{$\begin{array}{l}\text { Telecom } \\
\text { only } \\
\text { Steady } \\
\text { State }\end{array}$} & \multicolumn{2}{|c|}{ To FDI in Telecom } & \multirow{2}{*}{$\begin{array}{l}\text { Low imported } \\
\text { input share by } \\
\text { multinationals }\end{array}$} & \multirow{2}{*}{$\begin{array}{l}\text { WTO, } \\
\text { domestic } \\
\text { rent dissip. }\end{array}$} & \multirow{2}{*}{$\begin{array}{l}\text { Telecom, } \\
\text { domestic } \\
\text { rent dissip. }\end{array}$} \\
\hline & & & & & & Low barrier & High barrier & & & \\
\hline \multicolumn{11}{|l|}{ Quality-adjusted user price (\% change) } \\
\hline Ferrous metallurgy & 1.6 & 1.2 & 0.2 & 0.3 & 0.4 & 0.1 & 0.5 & 0.3 & 1.6 & 0.3 \\
\hline Non-ferrous metallurgy & 2.9 & 2.6 & 0.7 & 0.3 & 0.6 & 0.1 & 0.5 & 0.3 & 3.0 & 0.3 \\
\hline Chemical \& oil-chemical industry & 0.6 & 0.3 & 0.5 & 0.3 & 0.3 & 0.1 & 0.4 & 0.3 & 0.6 & 0.3 \\
\hline Mechanical engineering \& metal-working & -0.2 & -0.5 & 0.8 & 0.3 & 0.3 & 0.1 & 0.5 & 0.3 & -0.2 & 0.3 \\
\hline Timber \& woodworking \& pulp \& paper industry & -0.6 & -0.8 & -0.1 & 0.2 & 0.3 & 0.1 & 0.3 & 0.2 & -0.6 & 0.2 \\
\hline Construction materials industry & 0.2 & -0.2 & -0.3 & 0.3 & 0.3 & 0.1 & 0.5 & 0.3 & 0.2 & 0.3 \\
\hline Light industry & 0.3 & 0.1 & 0.7 & 0.2 & 0.1 & 0.1 & 0.4 & 0.2 & 0.3 & 0.2 \\
\hline Food industry & -0.3 & -0.6 & 0.6 & 0.3 & 0.1 & 0.1 & 0.4 & 0.3 & -0.4 & 0.2 \\
\hline Other industries & 1.1 & 1.0 & 0.5 & 0.1 & 0.1 & 0.0 & 0.1 & 0.1 & 1.1 & 0.1 \\
\hline Construction & 2.3 & 1.9 & 1.1 & 0.4 & 0.7 & 0.1 & 0.6 & 0.4 & 2.4 & 0.4 \\
\hline Railway transportation & -5.6 & -5.8 & -6.6 & 0.3 & 0.4 & 0.1 & 0.4 & 0.3 & -5.5 & 0.3 \\
\hline Truck transportation & -11.0 & -10.8 & -11.7 & -0.2 & -0.1 & 0.0 & -0.3 & -0.2 & -11.0 & -0.2 \\
\hline Pipelines transportation & -3.0 & -3.4 & -5.6 & 0.4 & 0.1 & 0.1 & 0.7 & 0.4 & -3.1 & 0.4 \\
\hline Maritime transportation & -3.3 & -3.1 & -3.8 & -0.1 & 0.0 & 0.0 & -0.2 & -0.1 & -3.3 & -0.1 \\
\hline Air transportation & -6.3 & -4.9 & -7.2 & -1.4 & -1.4 & -0.3 & -2.4 & -1.4 & -6.3 & -1.4 \\
\hline Other transportation & -8.3 & -8.1 & -9.4 & -0.1 & -0.2 & 0.0 & -0.2 & -0.1 & -8.3 & -0.1 \\
\hline Telecommunications & -19.8 & 2.5 & -21.2 & -21.6 & -21.6 & -5.1 & -33.0 & -21.5 & -19.8 & -21.6 \\
\hline Science \& science servicing (market) & -12.8 & -12.4 & -13.8 & -0.5 & -0.1 & -0.1 & -0.9 & -0.5 & -12.7 & -0.4 \\
\hline Financial services & -18.6 & -17.3 & -20.0 & -1.5 & -1.3 & -0.3 & -2.5 & -1.5 & -18.6 & -1.5 \\
\hline \multicolumn{11}{|l|}{ National firms' producer price (\% change) } \\
\hline Ferrous metallurgy & 1.1 & 0.5 & 1.3 & 0.5 & 1.0 & 0.1 & 0.9 & 0.5 & 1.2 & 0.6 \\
\hline Non-ferrous metallurgy & 2.1 & 1.6 & 1.4 & 0.5 & 0.9 & 0.1 & 0.9 & 0.5 & 2.3 & 0.6 \\
\hline Chemical \& oil-chemical industry & 0.6 & 0.1 & 1.4 & 0.5 & 0.9 & 0.1 & 0.8 & 0.5 & 0.7 & 0.6 \\
\hline Mechanical engineering \& metal-working & 0.1 & -0.3 & 1.3 & 0.4 & 0.9 & 0.1 & 0.7 & 0.4 & 0.2 & 0.5 \\
\hline Timber \& woodworking \& pulp \& paper industry & 0.0 & -0.4 & 1.3 & 0.4 & 0.9 & 0.1 & 0.7 & 0.4 & 0.1 & 0.5 \\
\hline Construction materials industry & 1.7 & 1.2 & 1.4 & 0.4 & 1.0 & 0.1 & 0.7 & 0.4 & 1.8 & 0.5 \\
\hline Light industry & -0.3 & -0.8 & 1.5 & 0.5 & 0.9 & 0.1 & 0.8 & 0.5 & -0.2 & 0.5 \\
\hline Food industry & 0.3 & -0.2 & 1.8 & 0.5 & 0.9 & 0.1 & 0.9 & 0.5 & 0.4 & 0.6 \\
\hline Other industries & 1.2 & 0.9 & 1.2 & 0.2 & 0.6 & 0.1 & 0.4 & 0.2 & 1.3 & 0.3 \\
\hline Construction & 2.7 & 2.2 & 1.2 & 0.5 & 0.7 & 0.1 & 0.7 & 0.4 & 2.8 & 0.5 \\
\hline Railway transportation & -2.1 & -2.7 & -3.6 & 0.6 & 1.1 & 0.1 & 1.0 & 0.6 & -1.9 & 0.7 \\
\hline Truck transportation & -4.1 & -4.5 & -5.4 & 0.5 & 1.0 & 0.1 & 0.7 & 0.5 & -4.0 & 0.5 \\
\hline Pipelines transportation & -1.0 & -1.5 & -3.0 & 0.6 & 0.6 & 0.1 & 0.9 & 0.5 & -1.0 & 0.6 \\
\hline Maritime transportation & -3.6 & -3.4 & -4.3 & -0.1 & 0.2 & 0.0 & -0.2 & -0.1 & -3.5 & 0.0 \\
\hline Air transportation & -1.7 & -1.1 & -3.0 & -0.6 & 0.0 & -0.1 & -1.0 & -0.6 & -1.5 & -0.5 \\
\hline Other transportation & -3.0 & -3.4 & -4.5 & 0.4 & 0.8 & 0.1 & 0.7 & 0.4 & -2.9 & 0.5 \\
\hline Telecommunications & -10.1 & 3.7 & -11.6 & -13.2 & -12.7 & -3.1 & -19.6 & -13.1 & -9.9 & -13.1 \\
\hline Science \& science servicing (market) & -9.9 & -9.6 & -10.9 & -0.3 & 0.2 & -0.1 & -0.5 & -0.3 & -9.7 & -0.2 \\
\hline Financial services & -9.8 & -9.1 & -11.2 & -0.7 & -0.1 & -0.2 & -1.2 & -0.7 & -9.6 & -0.6 \\
\hline
\end{tabular}


Table 8.

\begin{tabular}{|c|c|c|c|c|c|c|c|c|c|c|}
\hline \multirow[t]{2}{*}{ Scenarios and scenario definitions } & \multirow{2}{*}{ WTO } & \multirow{2}{*}{$\begin{array}{l}\text { WTO w/o } \\
\text { Telecom }\end{array}$} & \multirow{2}{*}{$\begin{array}{l}\text { Only FDI } \\
\text { Reform }\end{array}$} & \multirow{2}{*}{$\begin{array}{c}\text { Telecom } \\
\text { only }\end{array}$} & \multirow{2}{*}{$\begin{array}{c}\text { Telecom } \\
\text { only } \\
\text { Steady } \\
\text { State } \\
\end{array}$} & \multicolumn{2}{|c|}{ To FDI in Telecom } & \multirow{2}{*}{$\begin{array}{r}\text { Low imported } \\
\text {-input share by } \\
\text { multinationals }\end{array}$} & \multirow{2}{*}{$\begin{array}{c}\text { WTO, } \\
\text { domestic } \\
\text { rent dissip. }\end{array}$} & \multirow{2}{*}{$\begin{array}{l}\text { Telecom, } \\
\text { domestic } \\
\text { rent dissip. }\end{array}$} \\
\hline & & & & & & Low barrier & High barrier & & & \\
\hline \multicolumn{11}{|l|}{ Foreign firms' producer price (\% change) } \\
\hline Ferrous metallurgy & 0.8 & 0.3 & 1.3 & 0.5 & 0.9 & 0.1 & 0.9 & 0.5 & 0.9 & 0.6 \\
\hline Non-ferrous metallurgy & 1.3 & 0.7 & 1.4 & 0.5 & 0.9 & 0.1 & 0.8 & 0.5 & 1.4 & 0.6 \\
\hline Chemical \& oil-chemical industry & 0.4 & -0.2 & 1.4 & 0.5 & 0.9 & 0.1 & 0.8 & 0.5 & 0.5 & 0.6 \\
\hline Mechanical engineering \& metal-working & -0.4 & -0.8 & 1.3 & 0.4 & 0.9 & 0.1 & 0.7 & 0.4 & -0.3 & 0.5 \\
\hline Timber \& woodworking \& pulp \& paper industry & -0.6 & -1.1 & 1.3 & 0.4 & 0.9 & 0.1 & 0.7 & 0.4 & -0.5 & 0.5 \\
\hline Construction materials industry & 0.7 & 0.2 & 1.3 & 0.5 & 0.9 & 0.1 & 0.7 & 0.4 & 0.8 & 0.5 \\
\hline Light industry & -0.6 & -1.1 & 1.5 & 0.5 & 0.9 & 0.1 & 0.8 & 0.5 & -0.4 & 0.6 \\
\hline Food industry & -0.4 & -1.0 & 1.7 & 0.5 & 0.9 & 0.1 & 0.9 & 0.5 & -0.3 & 0.6 \\
\hline Other industries & 0.5 & 0.2 & 1.2 & 0.3 & 0.7 & 0.1 & 0.5 & 0.3 & 0.6 & 0.4 \\
\hline Construction & 2.7 & 2.2 & 1.2 & 0.5 & 0.7 & 0.1 & 0.7 & 0.4 & 2.8 & 0.5 \\
\hline Railway transportation & 23.5 & 22.8 & 21.6 & 0.6 & 1.1 & 0.1 & 0.9 & 0.6 & 23.7 & 0.7 \\
\hline Truck transportation & 21.1 & 20.6 & 19.5 & 0.4 & 1.0 & 0.1 & 0.7 & 0.4 & 21.3 & 0.5 \\
\hline Pipelines transportation & 24.9 & 24.2 & 22.3 & 0.6 & 0.6 & 0.1 & 0.9 & 0.5 & 24.9 & 0.6 \\
\hline Maritime transportation & 3.1 & 3.3 & 2.4 & -0.1 & 0.2 & 0.0 & -0.2 & -0.1 & 3.2 & -0.1 \\
\hline Air transportation & 5.3 & 5.9 & 3.9 & -0.6 & 0.0 & -0.1 & -1.0 & -0.6 & 5.4 & -0.5 \\
\hline Other transportation & 22.4 & 21.9 & 20.5 & 0.4 & 0.8 & 0.1 & 0.7 & 0.4 & 22.5 & 0.5 \\
\hline Telecommunications & 13.5 & 3.6 & 11.6 & 9.7 & 10.2 & 4.8 & 10.8 & 9.6 & 13.7 & 9.7 \\
\hline Science \& science servicing (market) & 14.0 & 14.3 & 12.8 & -0.3 & 0.2 & -0.1 & -0.5 & -0.3 & 14.2 & -0.2 \\
\hline Financial services & 16.1 & 17.0 & 14.3 & -0.7 & -0.2 & -0.2 & -1.2 & -0.7 & 16.2 & -0.7 \\
\hline
\end{tabular}

